Distribution

Category UC-276

SAND94-2068

Unlimited Release

Printed August 1994

\title{
DEVELOPMENT OF CONCENTRATOR SOLAR CELLS
}

\author{
Applied Solar Energy Corporation \\ 15251 East Don Julian Road \\ City of Industry, CA 91746
}

Sandia Contract 54-2191B

\begin{abstract}
A limited pilot production run on PESC silicon solar cells for use at high concentrations ( 200 to 400 suns) is summarized. The front contact design of the cells was modified for operation without prismatic covers. The original objective of the contract was to systematically complete a process consolidation phase, in which all the process improvements developed during the contract would be combined in a pilot production run. This pilot run was going to provide a basis for estimating cell costs when produced at high throughput. Because of DOE funding limitations, the Photovoltaic Concentrator Initiative is on hold, and Applied Solar's contract was operated at a low level of effort for most of 1993. The results obtained from the reduced scope pilot run showed the effects of discontinuous process optimization and characterization. However, the run provided valuable insight into the technical areas that can be optimized to achieve the original goals of the contract.
\end{abstract}




\section{DISCLAIMER}

This report was prepared as an account of work sponsored by an agency of the Uinited States Government. Neither the United States Government nor any agency thereof, nor any of their employees, make any warranty, express or implied, or assumes any legal liability or responsibility for the accuracy, completeness, or usefulness of any information, apparatus, product, or process disclosed, or represents that its use would not infringe privately owned rights. Reference herein to any specific commercial product, process, or service by trade name, trademark, manufacture, or otherwise does not necessarily constiturte or imply its endorsement, recommendation, or favoring by the United States Government or any agency thereof. The views and opinions of authors expressed herein do not necessarily state or reflect those of the United States Government or any agency thereof. 


\section{DISCLAIMER}

Portions of this document may be illegible electronic image products. Images are produced from the best available original document. 
Table of Contents

1.0 INTRODUCTION $\ldots \ldots \ldots \ldots \ldots \ldots \ldots \ldots \ldots$

2.0 TECHNICAL RESULTS $\ldots \ldots \ldots \ldots \ldots \ldots \ldots$. 1

2.1 Pilot Run Details $\ldots \ldots \ldots \ldots \ldots \ldots \ldots \ldots \ldots$

2.2 Yields $\ldots \ldots \ldots \ldots \ldots \ldots \ldots \ldots \ldots \ldots \ldots \ldots$

2.3 Electrical Distribution $\ldots \ldots \ldots \ldots \ldots \ldots \ldots \ldots$

2.4 Comments $\ldots \ldots \ldots \ldots \ldots \ldots \ldots \ldots \ldots \ldots \ldots$

3.0 ChaRACTERIZATION TESTS . . . . . . . . 4

3.1 Measurements at High Concentrations ......... 4

3.2 Spectral Response $\ldots \ldots \ldots \ldots \ldots \ldots \ldots \ldots \ldots$

3.3 Dark Forward Diode Measurements $\ldots \ldots \ldots \ldots \ldots$

3.3.1 Diode Ideality Factor $\ldots \ldots \ldots \ldots \ldots \ldots \ldots$

3.3.2 Shunt Leakage Currents $\ldots \ldots \ldots \ldots \ldots \ldots \quad 5$

3.3.3 Series Resistance $\ldots \ldots \ldots \ldots \ldots \ldots \ldots \ldots$

3.4 Analysis of Performance at High Concentrations ... 6

3.4.1 Series Resistance from Model $\ldots \ldots \ldots \ldots \ldots 6$

3.4.2 Analysis of CFF Versus Concentration Curves .. 7

3.4.3 Discussion $\ldots \ldots \ldots \ldots \ldots \ldots \ldots \ldots \ldots$

4.0 CONCLUSIONS $\ldots \ldots \ldots \ldots \ldots \ldots \ldots \ldots \ldots \ldots$

5.0 REFERENCES $\ldots \ldots \ldots \ldots \ldots \ldots \ldots \ldots \ldots \ldots \ldots$. 9 


\subsection{INTRODUCTION}

This report summarizes a limited pilot production run on PESC silicon solar cells for use at high concentrations (200 - 400 suns). The cell front contact design was modified for operation without prismatic covers. The original objective of the contract was to systematically complete a process consolidation phase, in which all the process improvements developed during the contract would be combined in a pilot production run. This pilot run would demonstrate the current efficiency status of high concentration Si cells, and would provide a basis for estimating cell costs when produced at high throughput. Because of DOE funding limitations, the Concentrator Initiative is on hold, and Applied Solar's contract was operated at a low level of effort for most of 1993.

The results obtained from the reduced scope pilot run showed the effects of discontinuous process optimization and characterization. However, the run provided valuable insight into the technical areas which can be optimized to achieve the original contract goals.

\subsection{TECFINICAL RESULTS}

\section{$2.1 \quad$ Pilot Run Details}

Twenty 4-inch diameter Si wafers, with $0.2 \mathrm{ohm}-\mathrm{cm}$ resistivity, were processed in Applied Solar's Si production line. The process sequence used has been described in previous reports. Four photomasks were used to balance good cell efficiency with reduced costs. The micro-grooving, $\mathrm{P}+$ and $\mathrm{N}+$ diffusions, and surface passivation steps were developed earlier. The micro-grooving used an image-reversal process (to reduce the reflecting flats), but image-reversal was not used to form the front grid pattern. Previous tests showed that CFF values were higher if the back contacts were sintered at $525^{\circ} \mathrm{C}$. This high temperature led to some outdiffusion of the Al layer used in the PESC back contact, and caused some 
difficulties in obtaining void-free soldered joints. Also if the sintering was done after AR coating, a slight loss of $J_{S C}$ was observed. Original plans were to replace this sinter step with a rapid thermal anneal. It was not possible to include this rapid anneal step in time for the pilot run.

\section{$2.2 \quad$ Yields}

Twenty percent of the starting slices were lost after metal evaporation, or after sawing to size.

Twenty percent of the wafers were rejected early in the processing because of incomplete mask registration. This gave a mechanical yield of $60 \%$. For the remaining wafers, the electrical yield (cells $\geq 19 \%$ at 150 -suns, $30^{\circ} \mathrm{C}$ ) was around $70 \%$. i.e., overall yield was $60 \% \times 70 \%=42 \%$. As a result 200 cells with 150 -sun efficiency $>19 \%$ (and average 150-sun efficiency $20 \%$ ) were delivered.

\subsection{Electrical Distribution}

At average 150-suns, the average value of the major $I-V$ parameters was as follows:

\section{TABLE 1}

\begin{tabular}{|l|c|c|c|c|l||}
\hline & $\begin{array}{c}\mathrm{V}_{\text {oc }} \\
(\mathrm{mV})\end{array}$ & $\begin{array}{c}\mathrm{J}_{\text {sc }} \\
(\mathrm{A})\end{array}$ & $\begin{array}{c}\text { Pmax } \\
(\mathrm{W})\end{array}$ & $\begin{array}{c}\text { CFF } \\
(\%)\end{array}$ & $\begin{array}{c}\text { Efficiency } \\
(\%)\end{array}$ \\
\hline Average Value - 200 cells & 782 & 4.981 & 2.984 & 76.6 & 19.9 \\
& & 5.01 & 3.028 & 78.0 & 20.19 \\
\hline Average Value - 10 cells & 775 & 5.01 & \\
\hline
\end{tabular}

The average $I_{\mathrm{sC}}$ at one-sun was $33.2 \mathrm{~mA} / \mathrm{cm}^{2}$. For comparison, Sandia selected (at random) 10 cells and the average values (at $150 \mathrm{x}$ ) are also included, and show good agreement. 
Figure 1 and 2 show histogram plots for the efficiency and curve fill factors for the 200 cells.

\subsection{Comments}

The most important factor determining the one-sun output was the short circuit current density $\left(\mathrm{J}_{\mathrm{SC}}\right)$. The arerage one-sun value for $\mathrm{J}_{\mathrm{SC}}$ was 33.2 $\mathrm{mA} / \mathrm{cm}^{2}$, about $5-8 \%$ lower than the best $\mathrm{J}_{\mathrm{SC}}$ values observed in earlier tests using Si with similar quality, and the same masks and processes. At higher concentration, the low one-sun $J_{S c}$ value led to lower efficiency, although the major cause of reduced efficiency was CFF (see discussion in 3.4)

Within the 200 cell group, the efficiency spread was around $10 \%$, mostly from $J_{S C}$ variation $(7 \%)$ and partly from CFF spread (3\%). There was slight slise-to-slice variation in $\mathrm{J}_{\mathrm{SC}}$, since over half the slices included most of the cells with low $\mathrm{J}_{\mathrm{SC}}$. Tests below (3.1) showed that the minority carrier diffusion lengths $(\sim 150 \mu \mathrm{m})$ were comparable to values expected from Si with resistivity around $0.2 \mathrm{ohm}-\mathrm{cm}$. Ellipsometic measurements during processing showed that the surface passivation $\mathrm{Si}_{2}$ layer varied from $90 \AA \mathrm{SiO}_{2}$ to $300 \AA$. This spread in thickness could detune the $\mathrm{AR}$ coating, which was designed for $\mathrm{Si}_{2}$ thicknesses around $100 \AA$. Reflectance tests on 5 cells (see 3.2 below) showed average reflectance between $5 \%$ and $7 \%$ over most of the active wavelength range $(0.5-1 \mu \mathrm{m})$. The grid mask used contained line widths around $5 \mu \mathrm{m}$ (shadow loss $3.5 \%$ ), but actual measurements showed that the deposited gridline width was $7 \mu \mathrm{m}$, around $5 \%$ shadow loss.

Considering this shading, the measured reflectance around 5 - 7\% does not suggest that serious $\mathrm{J}_{\mathrm{SC}}$ loss was caused by detuning of the AR coating. Howerer, part of the $J_{S C}$ spread could have been caused by varying line widths. 
The $V_{O C}$ values obtained at one-sun and higher concentrations were similar to those observed previously, and did not affect the cell output significantly.

\subsection{CEARACTERIZATION TESTS}

Sandia selected ten cells at random from the 200 delivered cells, and as seen in Table 1, the average IV parameters for those 10 cells (tested at 150-suns) agreed closely with the average values for the 200 cells delivered.

Drs. Ruby and Basore performed very thorough tests on these cells, (numbered 1 through 10). The following sections summarize these Sandia test results, and show their value in analyzing the cell performance. We have focused attention on cells $2,4,7$, and 8 because $\# 2$ and $\# 4$ are close to the average, \#7 had high shunt leakage and \#8 had the best efficiency at high concentrations.

\subsection{Measurements at High Concentrations}

Table 2 shows the Sandia measurements at one-sun and concentration $6.2 x, 12 x, 50 x, 150 x, 250 x$ and $400 x$ for the four cells $2,4,7$, and 8 .

Figures 3 - 14 plot concentration on a log scale and show the variation of efficiency (Figures 3 - 6), CFF (Figures 7 - 10) and $V_{o c}$ (Figures 11 - 14).

The peak efficiency was around 50-suns, and the peak CFF around 12suns. The slope of the $V_{\text {oc }}$ vs $\ln X$ plot was slightly lower than the 26 $\mathrm{mV} /$ decade for ideality factor $n=1$, and decreased for concentrations above $150 x$. This $\mathrm{V}_{\mathrm{OC}}$ variation with concentration agrees closely with previous tests and confirms that the quality of the Si and the PN junction were comparable to earlier tests. 
The peak efficiency was determined mostly by the $J_{\text {Sc }}$ values (these were discussed in section 2.4).

The fall off in efficiency and CFF with concentration was caused by series resistance, and thus is discussed in more detail in Section 3.4.

\subsection{Spectral Response}

Measurement of cell response and reflectance as a function of wavelength, led to plots of external and internal quantum efficiencies. Using analysis developed in reference $1, \mathrm{Dr}$. Basore determined that the average bulk diffusion length was between 160 and $185 \mu \mathrm{m}$, and the rear surface recombination velocities were between 860 and $1,860 \mathrm{~cm} \mathrm{sec}^{-1}$. These values are considered satisfactory.

\subsection{Dark Forward Diode Measurements}

Two typical dark $\ell I-V$ curves (for cells $\# 2$ and $\# 7$ ) are shown in Figures 15 and 16. Three cell parameters can be defined from those curves.

\subsubsection{Diode Ideality Factor}

The factor $\mathbf{n}$ in the Boltzman factor $\underline{\mathrm{nkT}} / \mathbf{q}$ can be determined by the slope of the curve at medium high diode currents (injection level). Fairly consistent n-values, between 1.05 and 1.2, were found for all ten cells.

\subsubsection{Shunt Leakage Currents}

The current at low voltages ( $\leq 0.3 \mathrm{~V}$ ) showed the PN junction shunt leakage. For the two cells shown, \#2 had high shunt resistance, and \#7 had low shunt resistance. The effects of the leakage currents on cell behavior is pronounced only at low concentrations. At one-sun, the curve fill factor for $\# 2$ and $\# 7$ were respectively 0.816 and 0.612 . However, for 
concentrations above 10x, the generated currents are much higher than the leakage currents, and the CFF is controlled by series resistance (see 3.4).

\subsubsection{Series Resistance}

The fall off in linearity at high currents is an indication of voltage dropped across the series resistance, and is typically measured as the $\Delta V$ at high currents such as 10 or $15 \mathrm{~A} / \mathrm{cm}^{2}$ ( $\Delta V$ is indicated on the curves, along with estimates of series resistance.

In 3.4 we discuss series resistive effects in detail, and have concluded that the $r_{s}$ value derived from the dark forward characteristic is not accurate. Possibly the cause is that under forward bias in the dark, the current flow pattern is different from the illuminated cell. Also the series voltage drop has opposing effect on the voltage across the diode in the circuit equations. The analysis in the next section gave $r_{s}$ values closer to predicted values, and gave guidelines for estimating the deficiencies in the current cells, and possible improvements which could be made.

\subsection{Analysis of Performance at High Concentrations}

\subsubsection{Series Resistance from Model}

Using the standard grid model for the separate contributions to series resistance, and inserting parameters used in designing the grid mask (and in processing) we obtain the following estimates:

$\begin{array}{lll}\text { Emitter Resistance } & \sim & 1 \text { milli-ohm } \\ \text { Front Contact Resistance } & \sim & 2 \text { milli-ohm } \\ \text { Bulk Resistance } & \sim & 6 \text { milli-ohm } \\ \text { Gridline Resistance } & \sim & 3 \text { milli-ohm }\end{array}$


In addition to these 12 milli-ohms, tests had shown that the back contact resistance could be significant (1-5 milli-ohms), although the sintering cycle used was intended to reduce this resistance (as mentioned with trade-offs in ease of soldering and a small loss in $\mathrm{J}_{\mathrm{SC}}$ ).

\subsubsection{Analysis of CFF Versus Concentration Curves}

We used the same cells $(2,4,7$ and 8$)$ discussed in 3.1 .

Using Sandia's test results for concentrations of 50, 150, 250 and 400 suns, we computed the ideal fill factor $\left(\mathrm{FF}_{0}\right)$ from equation 1.

$$
\begin{aligned}
& \mathrm{FF}_{0}=\frac{\underline{\mathrm{O}}_{O C}-\ln \left(\mathrm{v}_{O C}+0.72\right)}{\mathrm{v}_{\mathrm{OC}}+1} \\
& \mathrm{v}_{\mathrm{OC}}=\underset{\mathrm{nkT/q}}{\mathrm{v}_{O C}} \text { and we assumed } \mathrm{n} \sim \text { 1. i.e. } \mathrm{v}_{\mathrm{OC}}=\frac{\mathrm{v}_{O C} \cdot}{26}
\end{aligned}
$$

These FF/FF。 values were then used to derive the FF/FF。 ratio from equation 2.

(2) $\quad \frac{\mathrm{FF}}{\mathrm{FF}}=\frac{\left(1-\mathrm{r}_{\mathrm{o}}\right)}{\mathrm{Rs}}$ where $r_{\mathrm{s}}$ is the series resistance

$$
\text { and } \quad R_{s}=\frac{0.9 v_{O C}}{I_{S C}}
$$

At each concentration we calculated $\mathrm{FF} / \mathrm{FF}$ 。 for the $5 r_{s}$ values $(0,5,10$, 15 and 20 milli-obms) and these are shown in Tables 3 - 6.

The values of efficiency versus concentration are plotted (on a linear scale) in Figures $17-20$. The dashed lines show the changing efficiency as a function of concentration for five values of modeled series resistance $\mathbf{r}_{\mathbf{s}}$. The solid line shows the measured variation and by comparison, it can be seen that the approximate $r_{s}$ values are as follows: 
TABLE 7

\begin{tabular}{||l|c|c|c|c|}
\hline Cell No. & 2 & 4 & 7 & 8 \\
\hline Series Resistance (m-0hm) & 12 & 9.5 & 13 & 12 \\
\hline
\end{tabular}

We see that low series resistance slightly affects the maximum efficiency ( $\sim 150$ suns), but the maximum value is more dependent on $\mathrm{J}_{\mathrm{sc}}$ •

As expected, the value of series resistance determines the rate of fall off in efficiency at higher concentrations.

\subsubsection{Discussion}

The spread in $r_{3}$ values is consistent with deviations from the modeled values in 3.4.1. Also the analysis shows that all series resistance contributions (especially grid resistance), must be reduced to approach the slow fall off for $r_{s}$ values $<10$ milli-ohms. It appears that close attention to reduced $r_{s}$ values must be combined with increased $J_{S c}$, to achieve high peak values of efficiency, and to reduce the fall off beyond the concentration giving peak efficiency.

\subsection{CONCLUSIONS}

This abbreviated run and the Sandia characterization tests have provided useful information on the achievable performance of these high concentration cells.

Fine-tuning of the series resistance can be completed by a systematic process consolidation and the performance validated by testing at higher concentrations. 
The most important requirement is to increase $\mathrm{J}_{\mathrm{SC}}$ to the levels consistent with the starting silicon. This can be confirmed by one-sun measurements using the designed masks and the processes developed by iterative testing.

\subsection{REFERENCES}

1. P. A. Basore, "Extended Spectral Analysis of Internal Quantum Efficiency," Conference Record of 23rd IEEE PVSC, July 1993, p. 147. 
Table 2

Sandia Test Results at Different Concentrations

Cell \#2

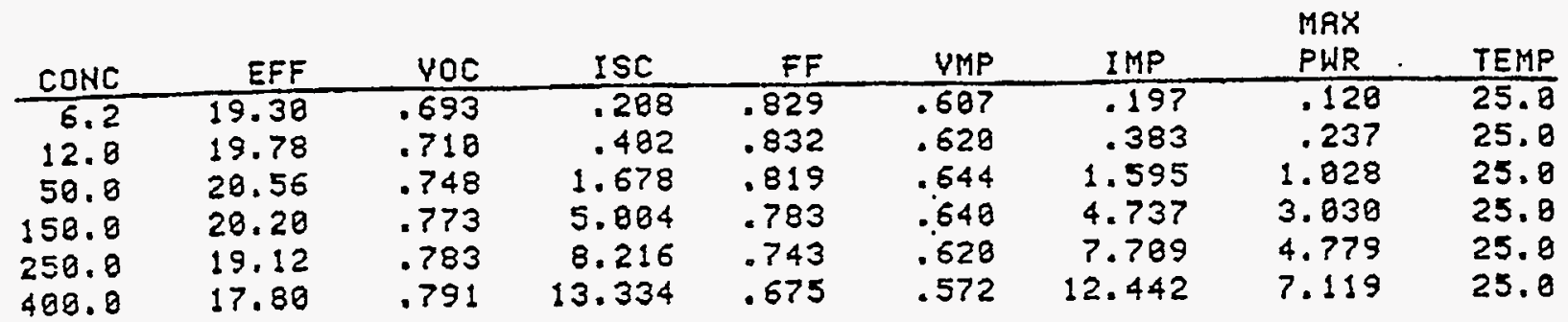

Cell \#4

\begin{tabular}{rrrrrrrrr} 
CONC & EFF & YOC & ISC & FF & UMP & IMP & PHR & TEMP \\
\hline 6.2 & 18.61 & .599 & .285 & .887 & .686 & .191 & .115 & 25.8 \\
12.8 & 19.39 & .716 & .395 & .822 & .629 & .378 & .233 & 25.8 \\
58.8 & 28.37 & .754 & 1.642 & .822 & .652 & 1.562 & 1.818 & 25.0 \\
158.8 & 28.25 & .778 & 4.936 & .792 & .658 & 4.575 & 3.838 & 25.8 \\
258.8 & 19.65 & .787 & 8.248 & .757 & .638 & 7.797 & 4.913 & 25.8 \\
408.8 & 18.84 & .794 & 13.826 & .698 & .593 & 12.169 & 7.216 & 25.8
\end{tabular}

Cell \#7

\begin{tabular}{|c|c|c|c|c|c|c|c|c|}
\hline CONC & $E F F$ & VOC & ISC & $F F$ & UMP & IMP & $\begin{array}{l}\text { MAX } \\
\text { PWR } \\
\end{array}$ & TEMP \\
\hline 6.2 & 18.11 & .696 & .284 & .792 & .689 & .185 & .112 & 25.8 \\
\hline 12.8 & 18.84 & .712 & .392 & .818 & .622 & .364 & .226 & 25.8 \\
\hline 58.8 & 19.88 & .758 & 1.534 & .811 & .643 & 1.546 & .994 & $25 . \theta$ \\
\hline 150.0 & 19.38 & .775 & 4.892 & .360 & .629 & 4.619 & 2.986 & 25.8 \\
\hline 258.8 & 18.85 & .786 & 7.983 & .728 & .588 & 7.423 & 4.512 & 25.8 \\
\hline 488.0 & 16.45 & .793 & 12.884 & .644 & .572 & 11.498 & 6.579 & 25.8 \\
\hline
\end{tabular}

Cell \#8

\begin{tabular}{|c|c|c|c|c|c|c|c|c|}
\hline CONC & $E F F$ & Yoc & ISC & $F F$ & UMP & IMP & $\begin{array}{l}\text { MRX } \\
\text { PWR }\end{array}$ & TEMP \\
\hline 6.2 & 28.79 & .784 & .219 & .836 & .616 & .289 & .129 & 25.8 \\
\hline 12.8 & 21.06 & .721 & .422 & .831 & .631 & .481 & .253 & 25.8 \\
\hline 50.8 & 21.83 & .757 & 1.753 & .823 & .652 & 1.674 & 1.891 & 25.0 \\
\hline 158.8 & 21.49 & .782 & 5.283 & .781 & .643 & 5.215 & 3.223 & 25.8 \\
\hline 250.0 & 28.15 & .791 & 8.656 & .736 & .619 & 8.135 & 5.837 & 25.0 \\
\hline 400.0 & 18.51 & .798 & 13.974 & .664 & .593 & 12.495 & 7.484 & 25.8 \\
\hline
\end{tabular}


TABLE 3

Efficiency rs. Concentration (Cell \#2)

\begin{tabular}{|c|c|c|c|c|c|c|c|c|c|}
\hline \multicolumn{5}{|c|}{ - Experimental } & \multicolumn{4}{|c|}{-_Calculated } & \multirow{2}{*}{$\frac{\cdots}{\overline{E F F}}$} \\
\hline Conc'n. & $\begin{array}{l}V_{o c} \\
(\mathrm{mV})\end{array}$ & $\begin{array}{l}I_{s c} \\
(A) \\
\end{array}$ & $\mathrm{FF}$ & $\begin{array}{l}\mathrm{EFF} \\
(\%)\end{array}$ & FFo & $\begin{array}{c}\mathbf{r}_{\mathbf{3}} \\
(\mathrm{m} \Omega)\end{array}$ & $\mathrm{FF} / \mathrm{FF} \mathrm{O}$ &. $\mathrm{FF}$ & \\
\hline 50 & 748 & 1.678 & .819 & 20.56 & .853 & $\begin{array}{l}0 \\
5 \\
10 \\
15 \\
20\end{array}$ & $\begin{array}{l}1 \\
0.987 \\
0.975 \\
0.963 \\
0.950\end{array}$ & $\begin{array}{l}.853 \\
.842 \\
.832 \\
.821 \\
.810\end{array}$ & $\begin{array}{l}21.41 \\
21.14 \\
20.89 \\
20.61 \\
20.33\end{array}$ \\
\hline 150 & 773 & 5.004 & .783 & 20.2 & .856 & $\begin{array}{l}0 \\
0 \\
5 \\
10 \\
15 \\
20\end{array}$ & $\begin{array}{l}1 \\
0.964 \\
0.928 \\
0.892 \\
0.856\end{array}$ & $\begin{array}{l}.856 \\
.825 \\
.754 \\
.763 \\
.733\end{array}$ & $\begin{array}{l}22.07 \\
21.27 \\
20.48 \\
19.68 \\
18.9\end{array}$ \\
\hline 250 & 783 & 8.216 & .743 & 19.12 & .858 & $\begin{array}{l}0 \\
5 \\
10 \\
15 \\
20\end{array}$ & $\begin{array}{l}1 \\
0.942 \\
0.883 \\
0.825 \\
0.767\end{array}$ & $\begin{array}{l}.858 \\
.808 \\
.758 \\
.708 \\
.658\end{array}$ & $\begin{array}{l}22.08 \\
20.79 \\
19.51 \\
18.22 \\
16.93\end{array}$ \\
\hline 400 & 791. & 13.334 & .675 & 17.8 & .859 & $\begin{array}{l}0 \\
5 \\
10 \\
15 \\
20\end{array}$ & $\begin{array}{l}1 \\
0.905 \\
0.811 \\
0.716 \\
0.622\end{array}$ & $\begin{array}{l}.859 \\
.777 \\
.697 \\
.615 \\
.534\end{array}$ & $\begin{array}{l}22.65 \\
20.49 \\
18.38 \\
16.22 \\
14.08\end{array}$ \\
\hline
\end{tabular}


TABLE 4

Efficiency rs. Concentration (Cell \#7)

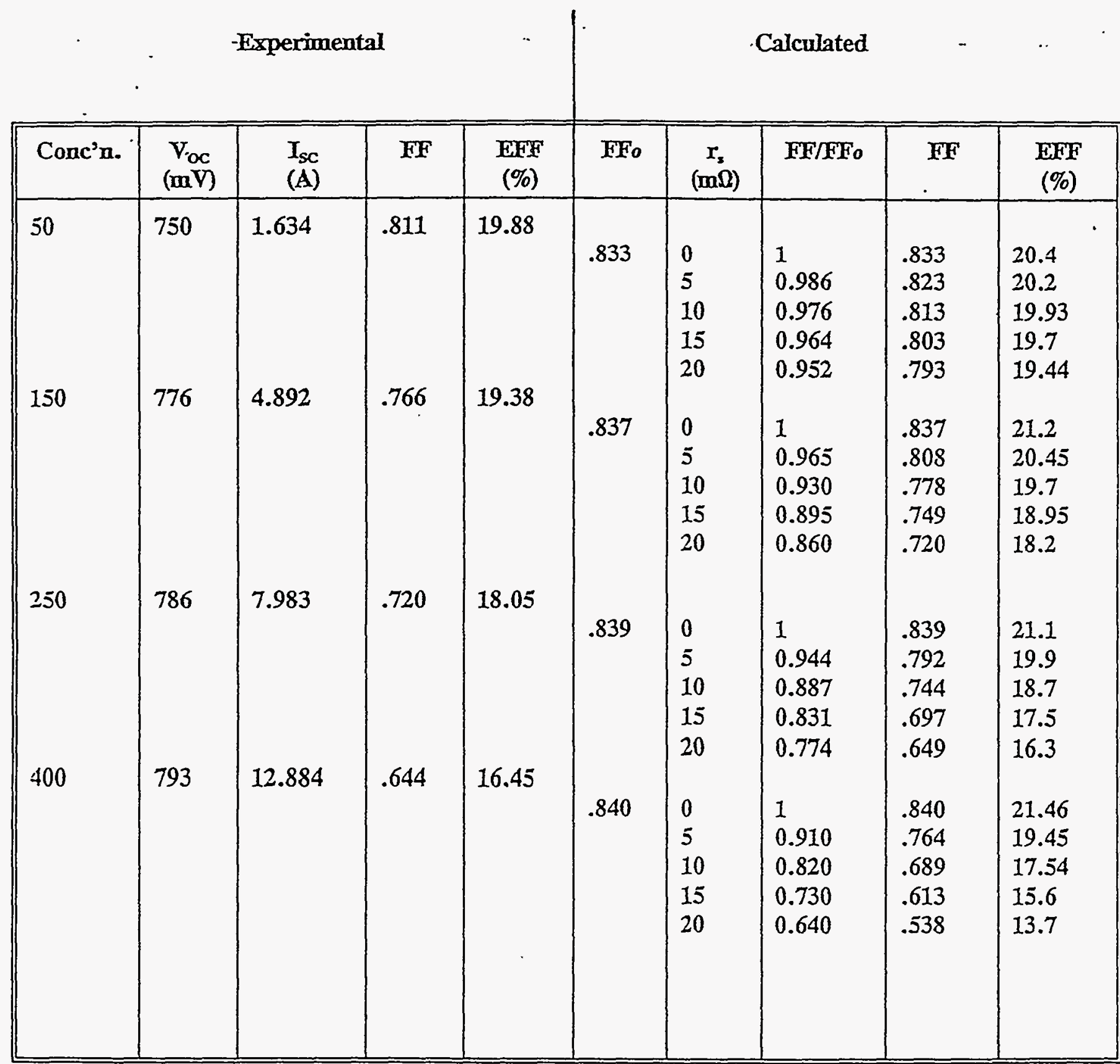


TABLE 5

Efficiency vs. Concentration (Cell \#4)

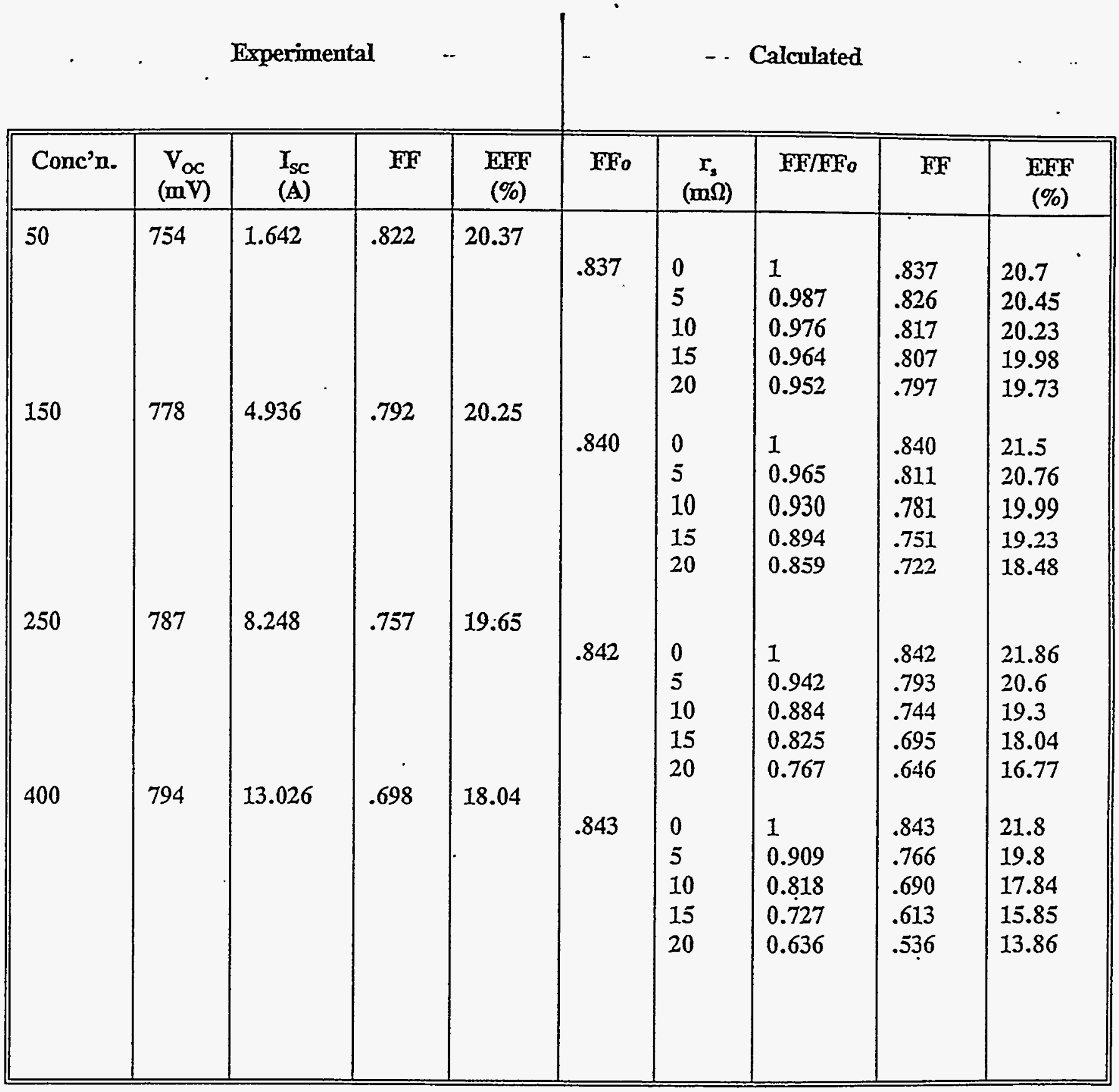


TABLE 6

Efficiency rs. Concentràtion (Cell \#8)

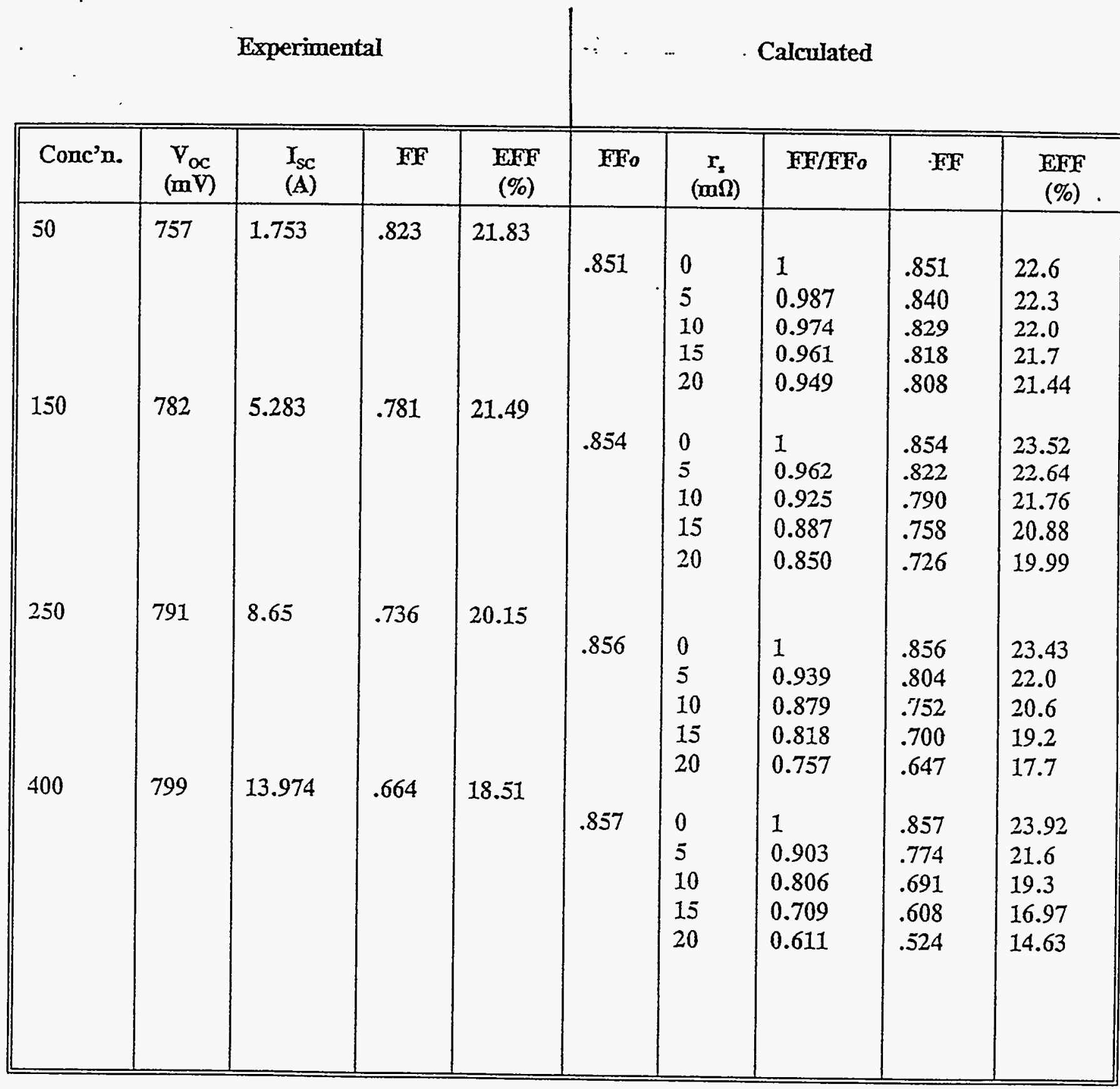


FIGURE 1 HISTOGRAM PLOT OF EFFICIENCY

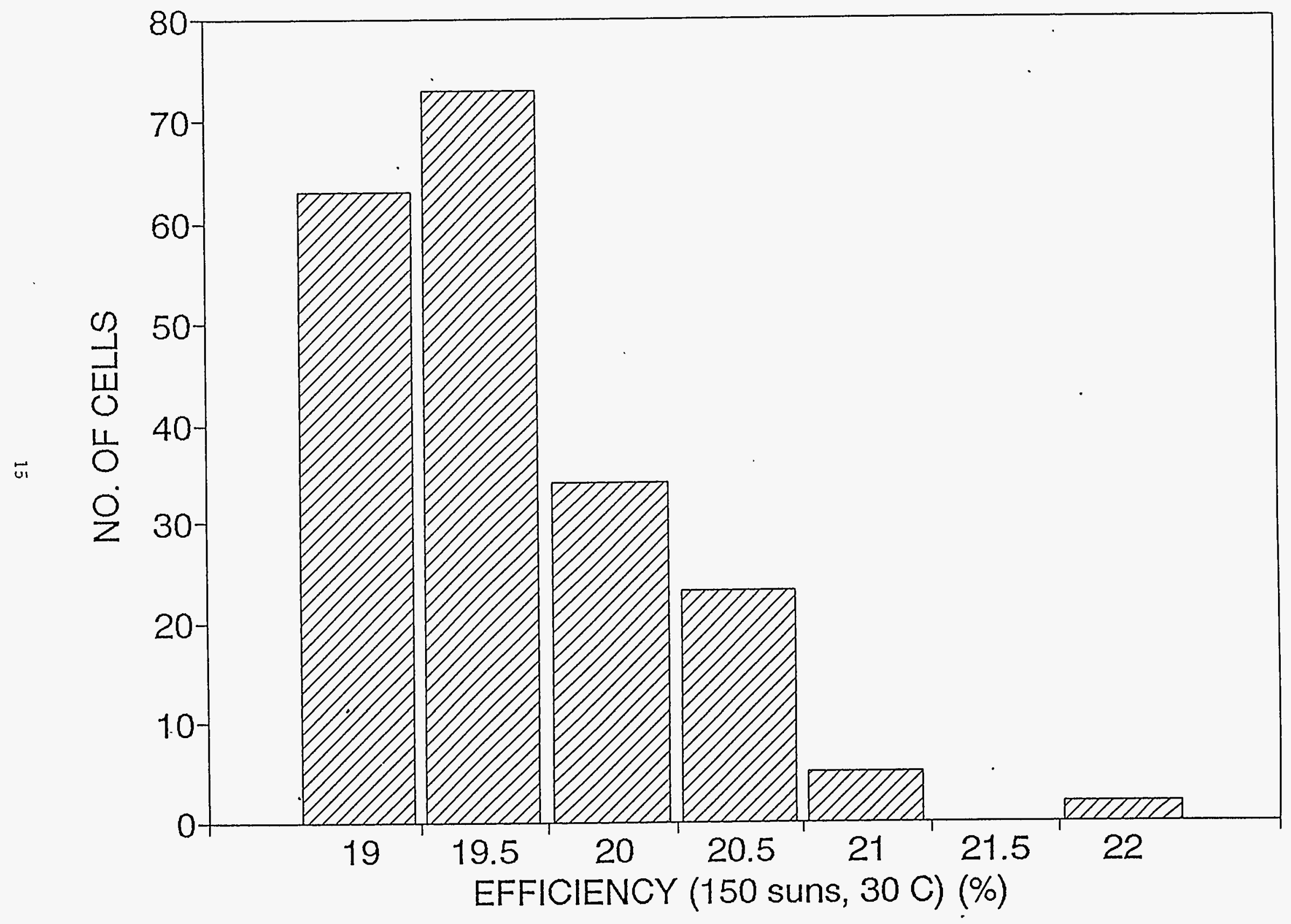


FIGURE 2 HISTOGRAM PLOT OF CFF

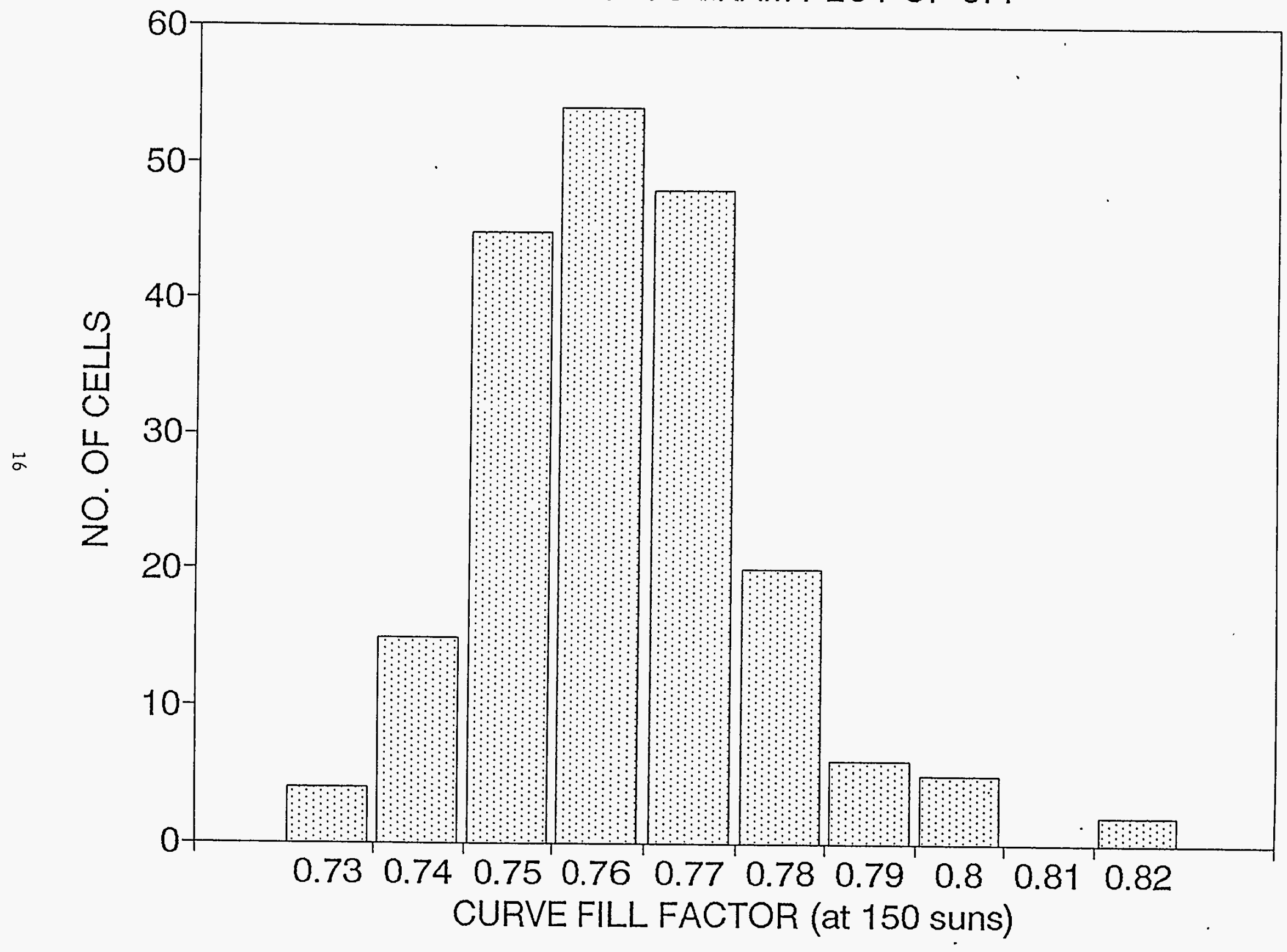




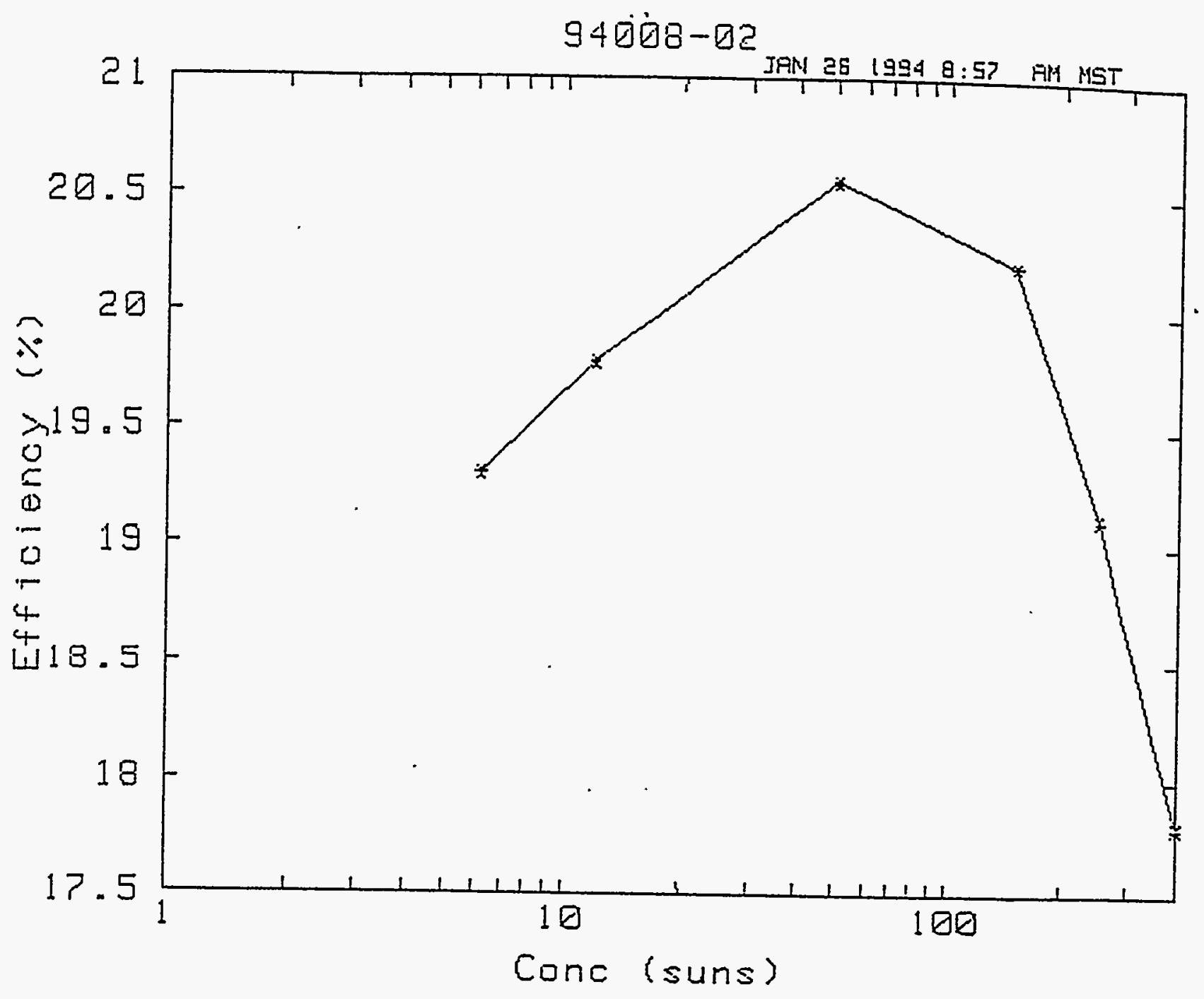

FIGURE 3

Efficiency Versus Concentration (Cell \#2) 


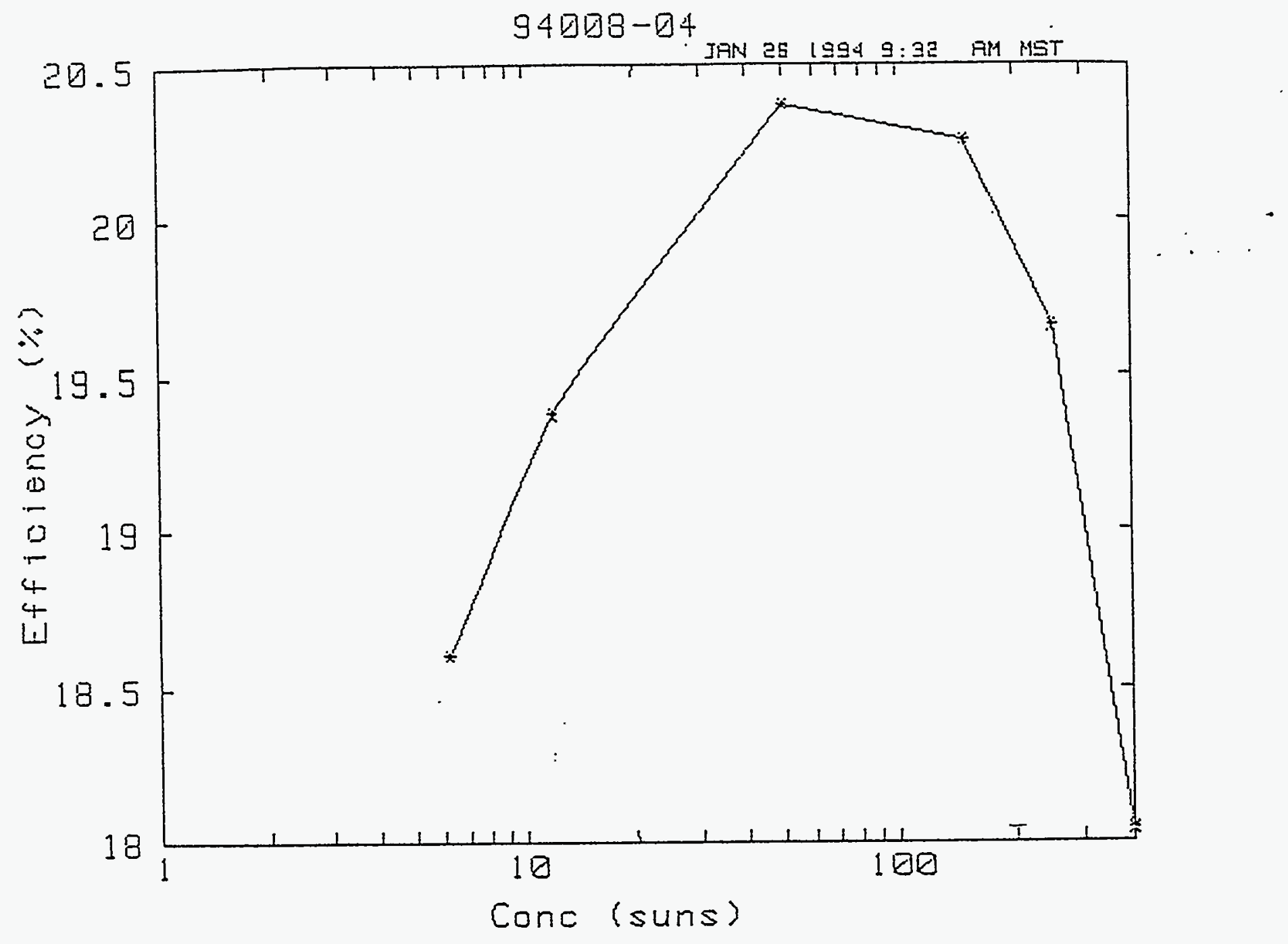

FIGURE 4

Efficiency Versus Concentration (Cell \#4) 


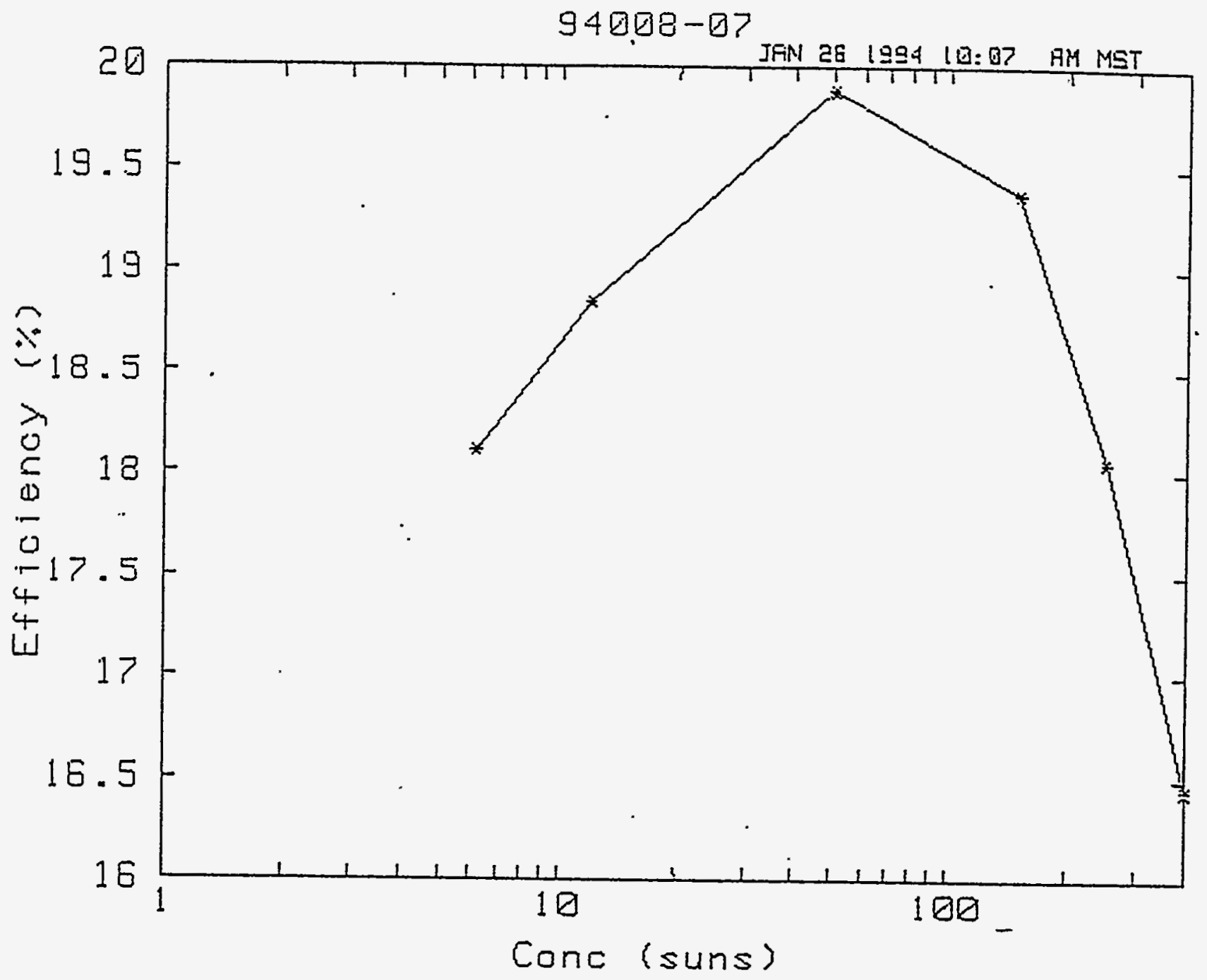

FIGURE 5

Efficiency Versus Concentration (Cell \#7) 


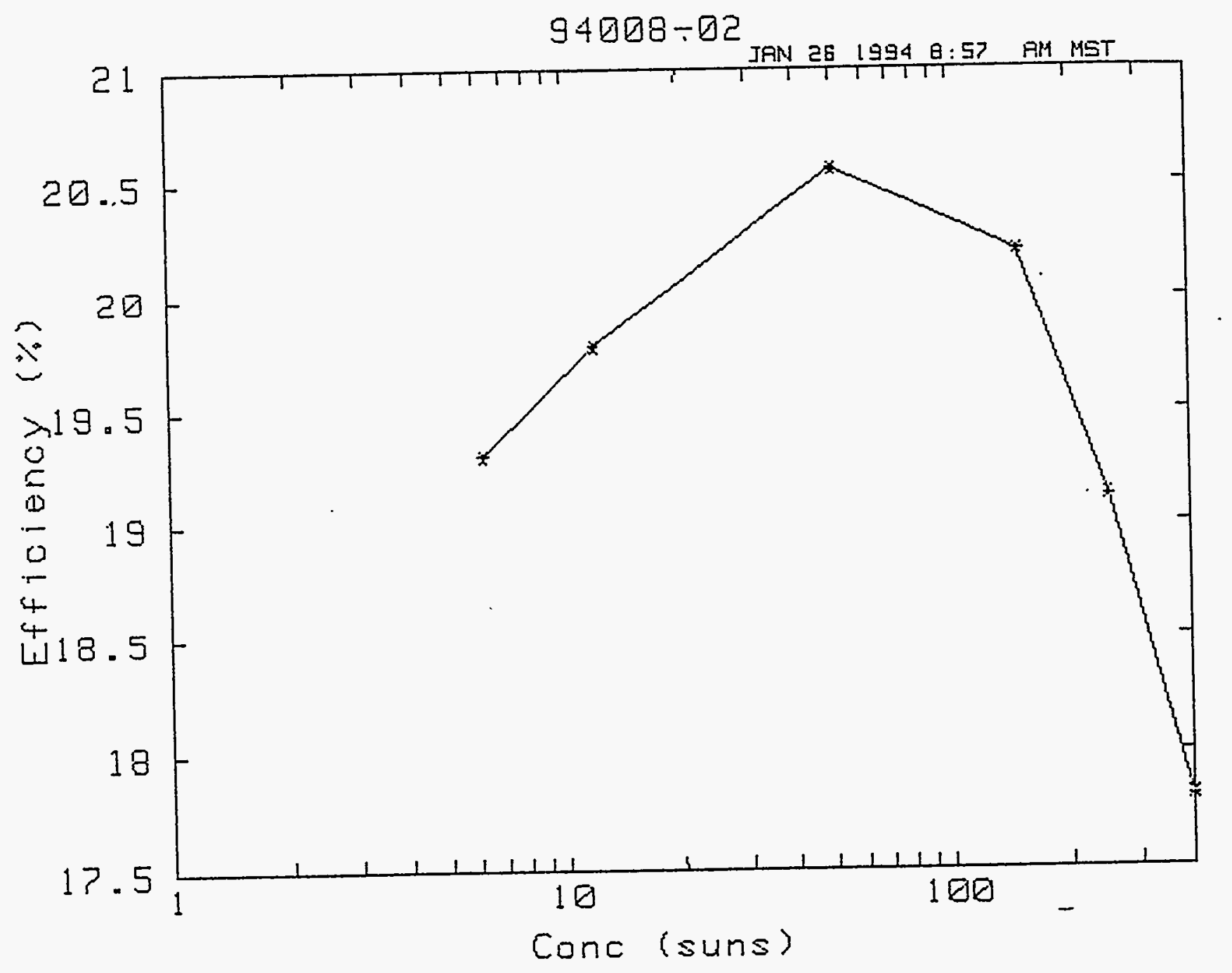

\section{FIGURE 6}

Efficiency Versus Concentration (Cell \#8) 


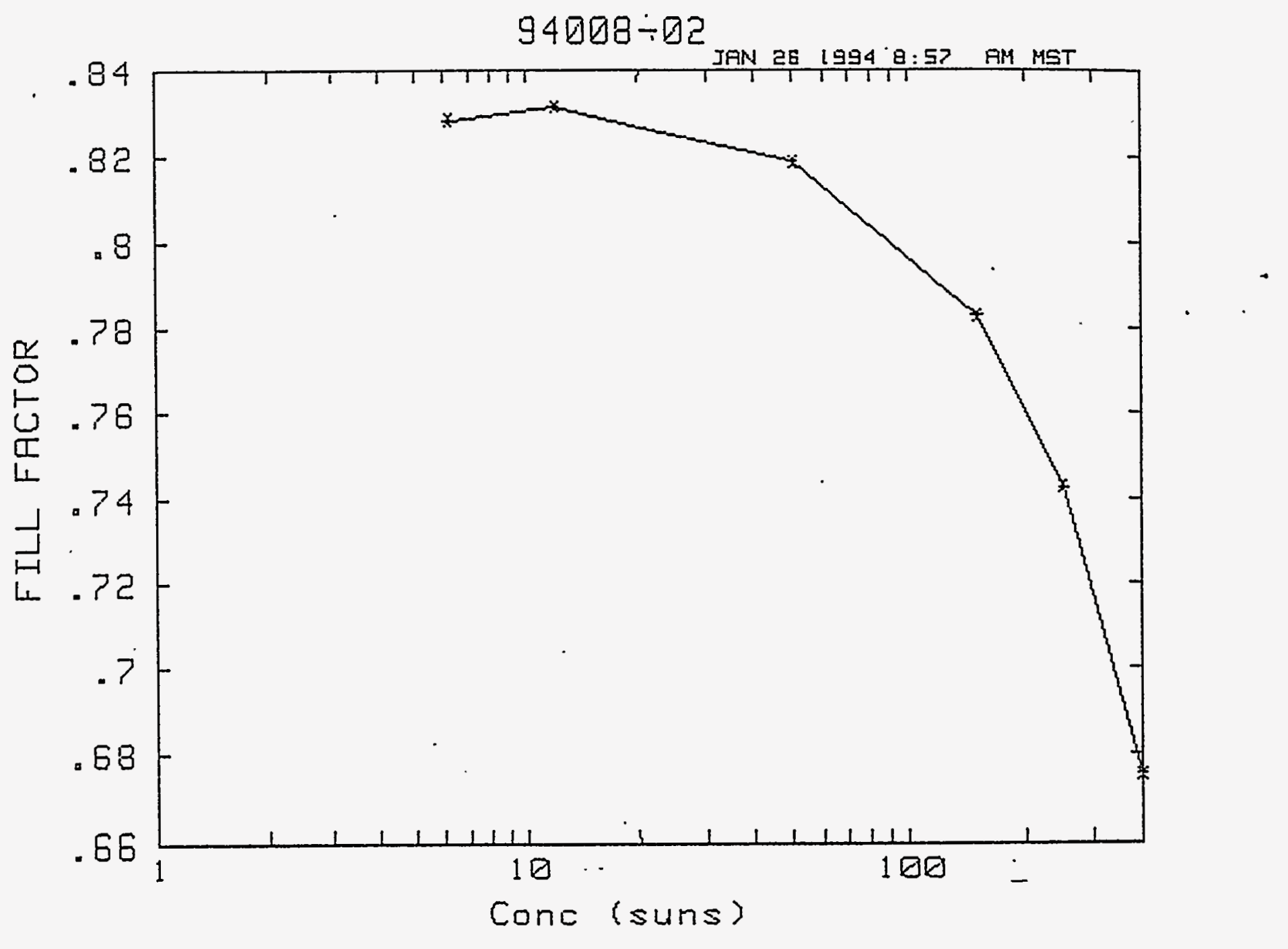

\section{FIGURE 7}

Curve Fill Factor Versus Concentration (Cell \#2) 


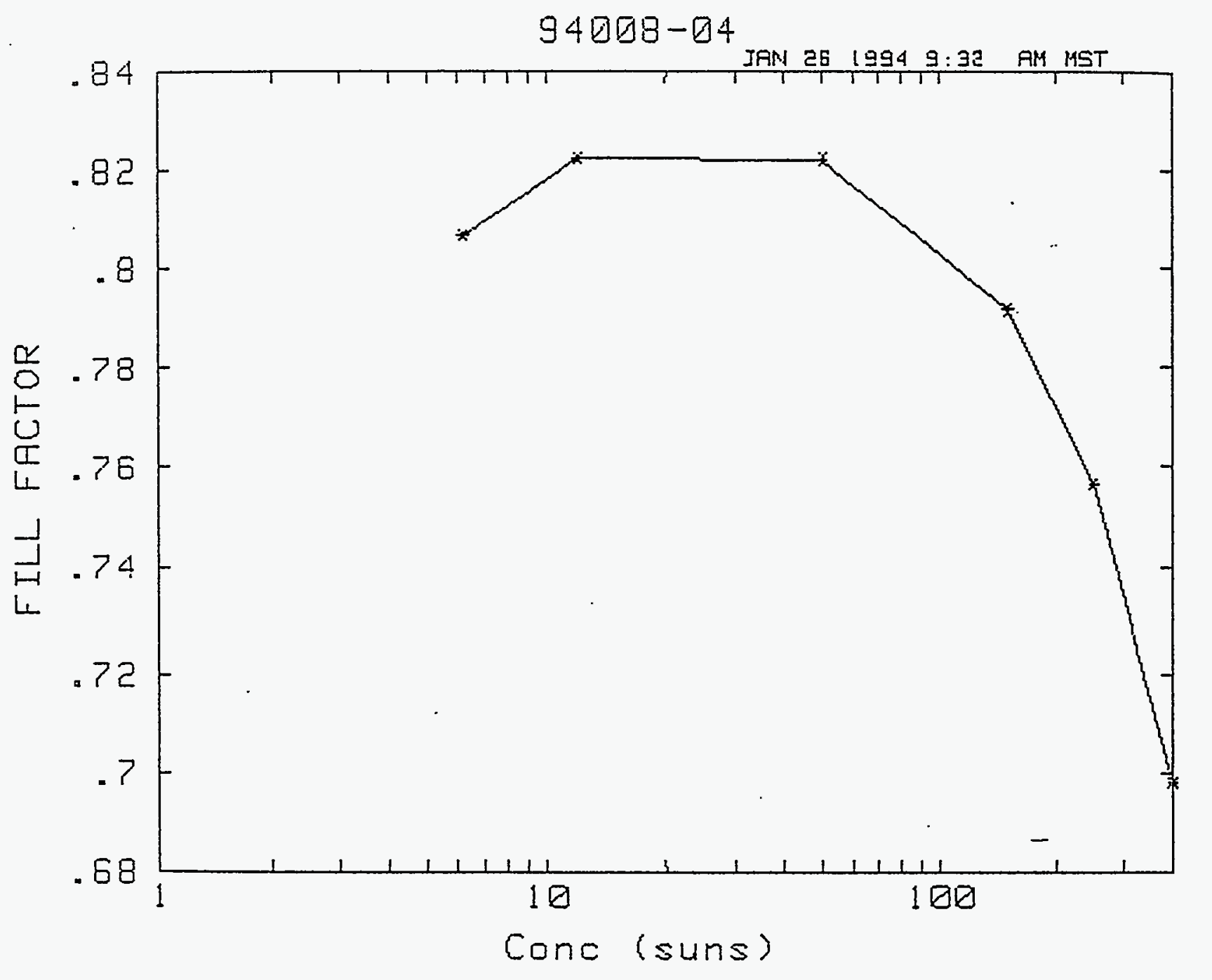

\section{FIGURE 8}

Curve Fill Factor Versus Concentration (Cell \#4) 


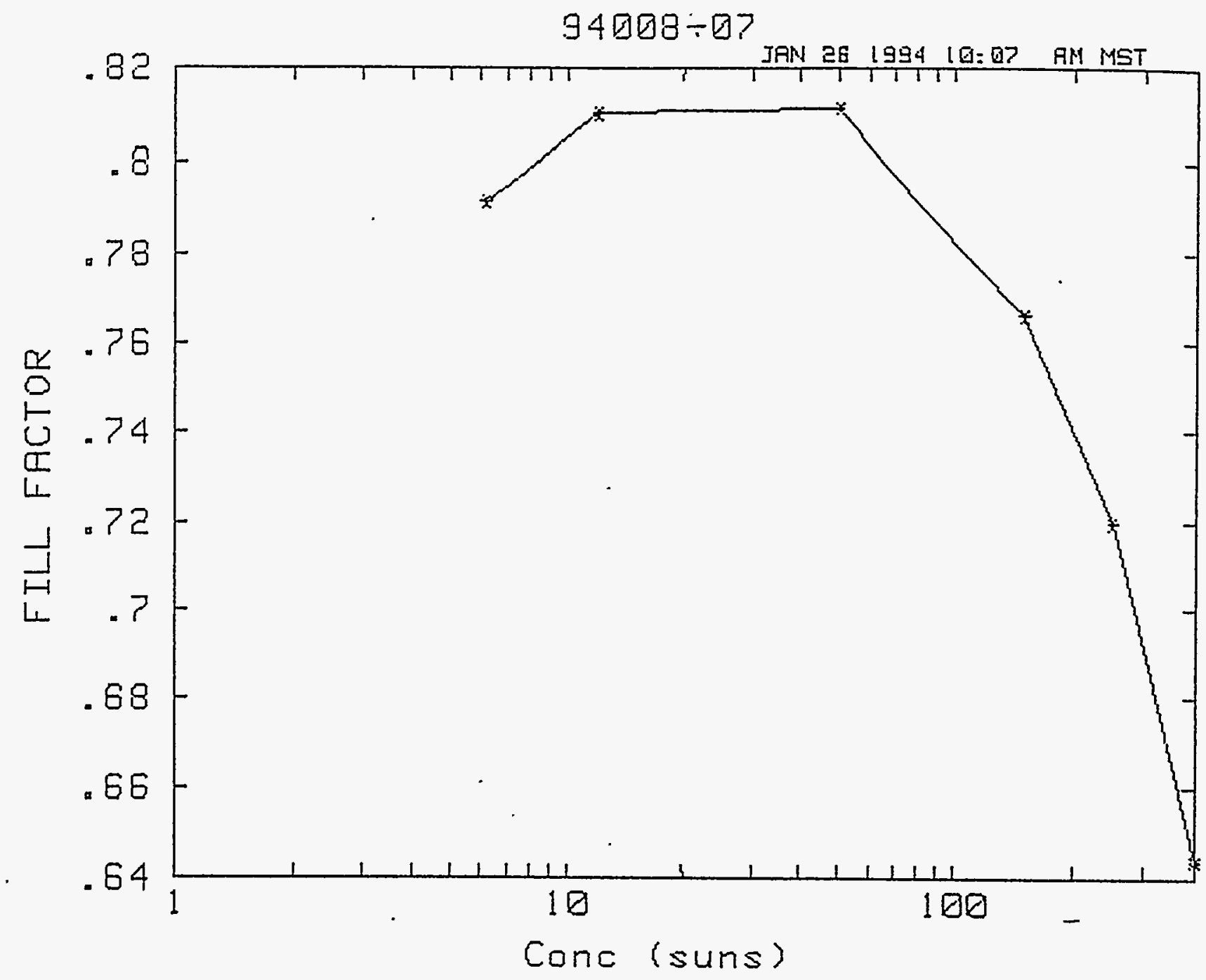

FIGURE 9

Curve Fill Factor Versus Concentration (Cell \#7) 


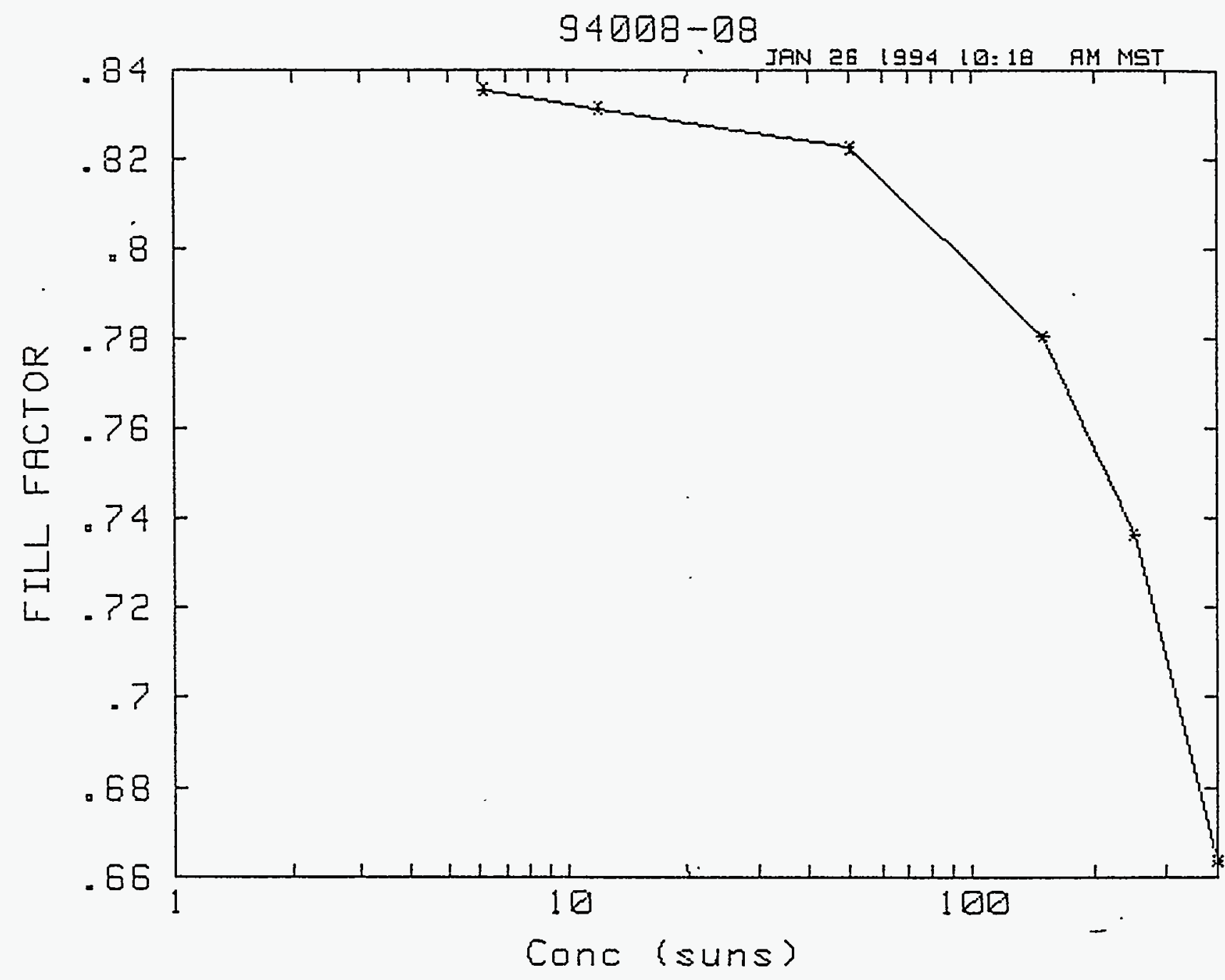

FIGURE 10

Curve Fill Factor Versus Concentration (Cell \#8) 


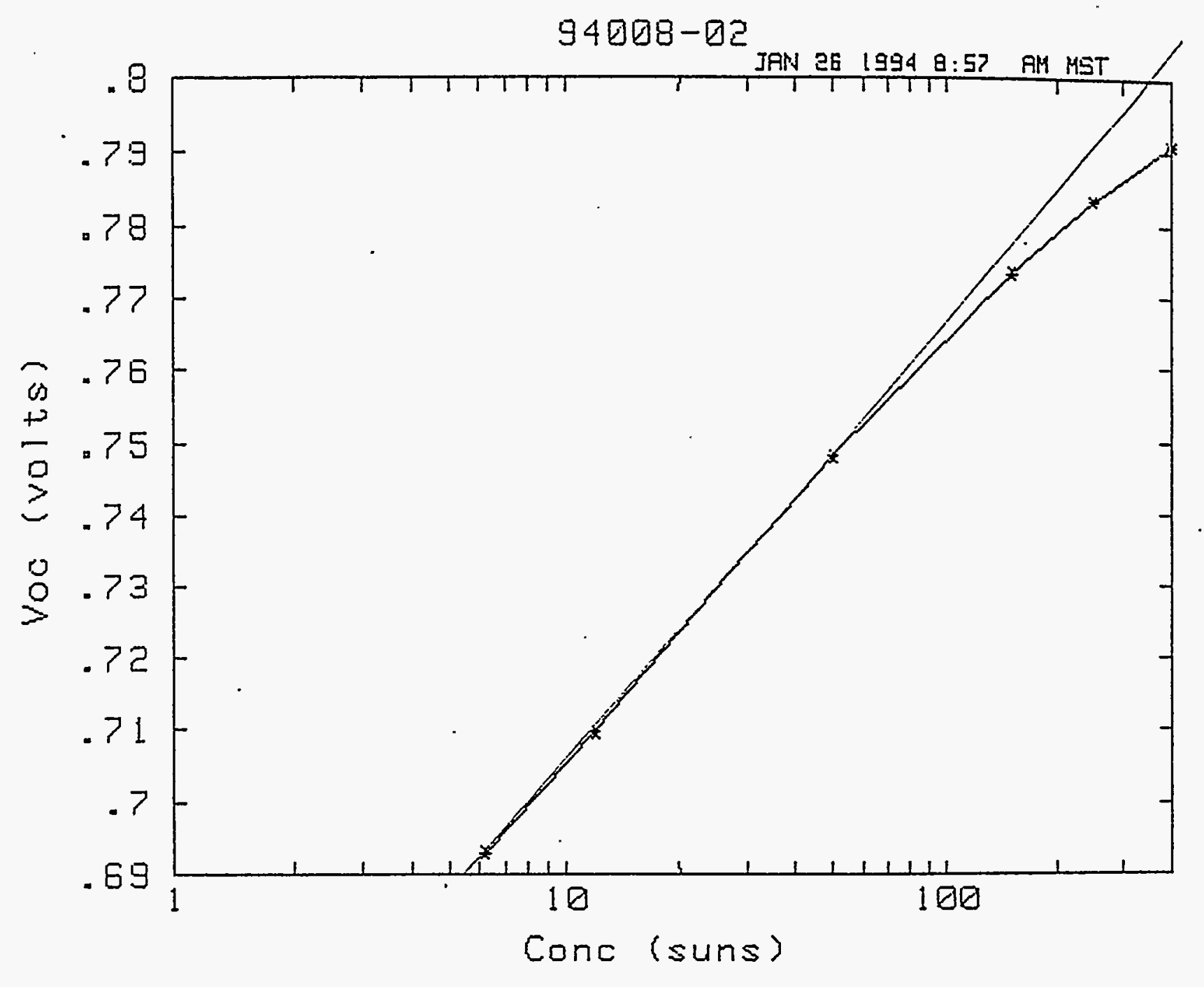

FIGURE 11

Open Circuit Voltage Versus Concentration (Cell \#2) 


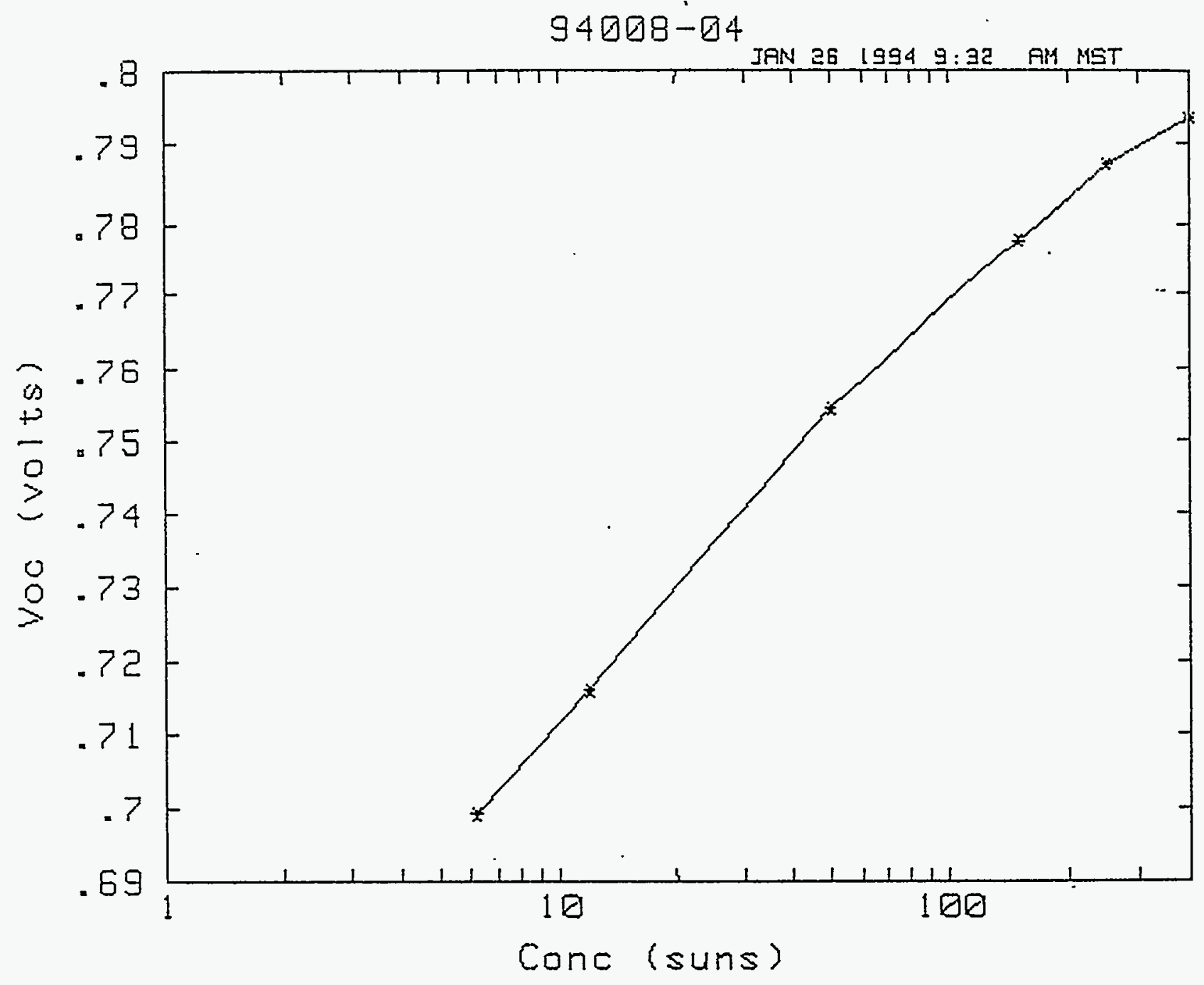

FIGURE 12

Open Circuit Voltage Versus Concentration (Cell \#4) 


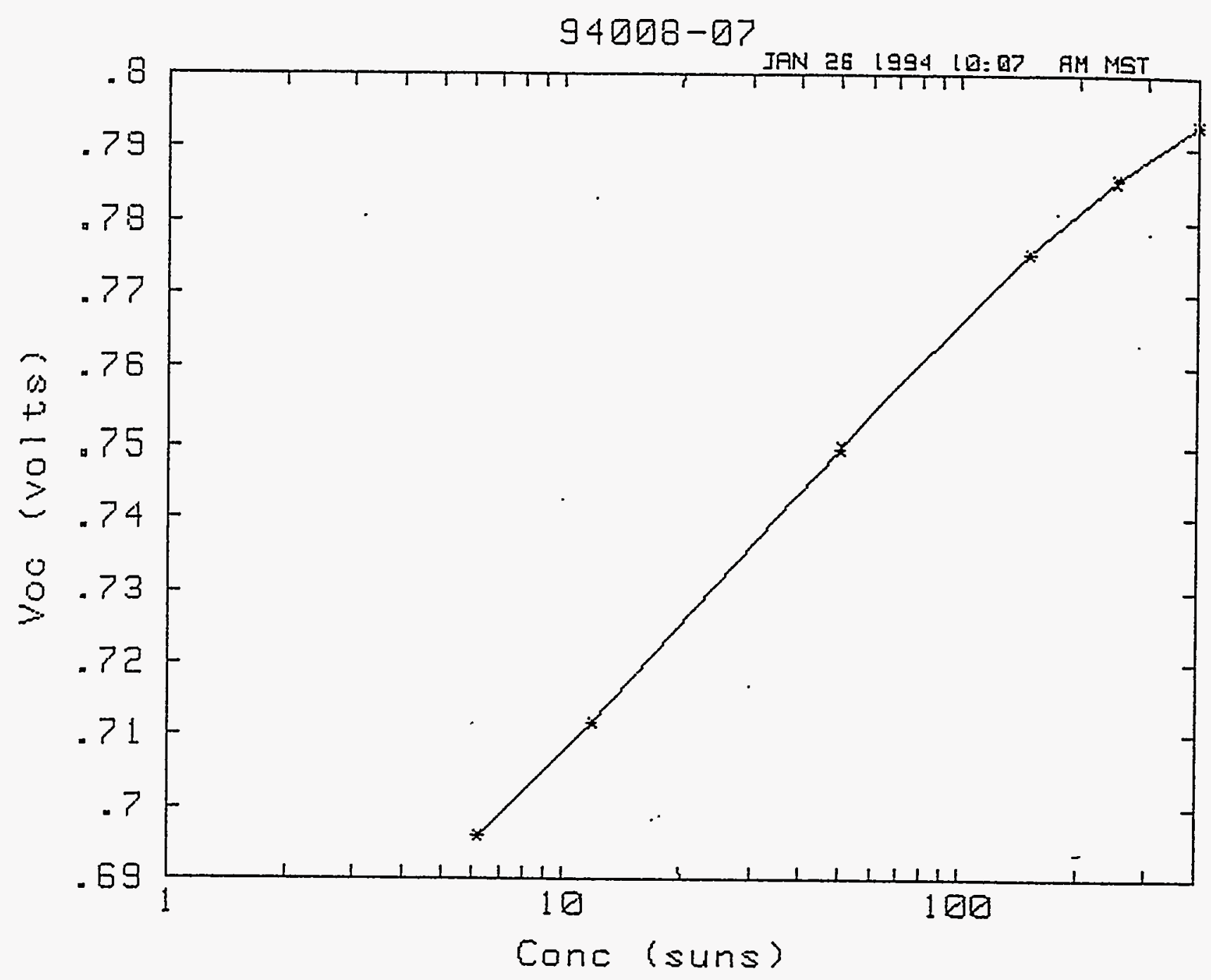

FIGURE 13

Open Circuit Voltage Versus Concentration (Cell \#7) 


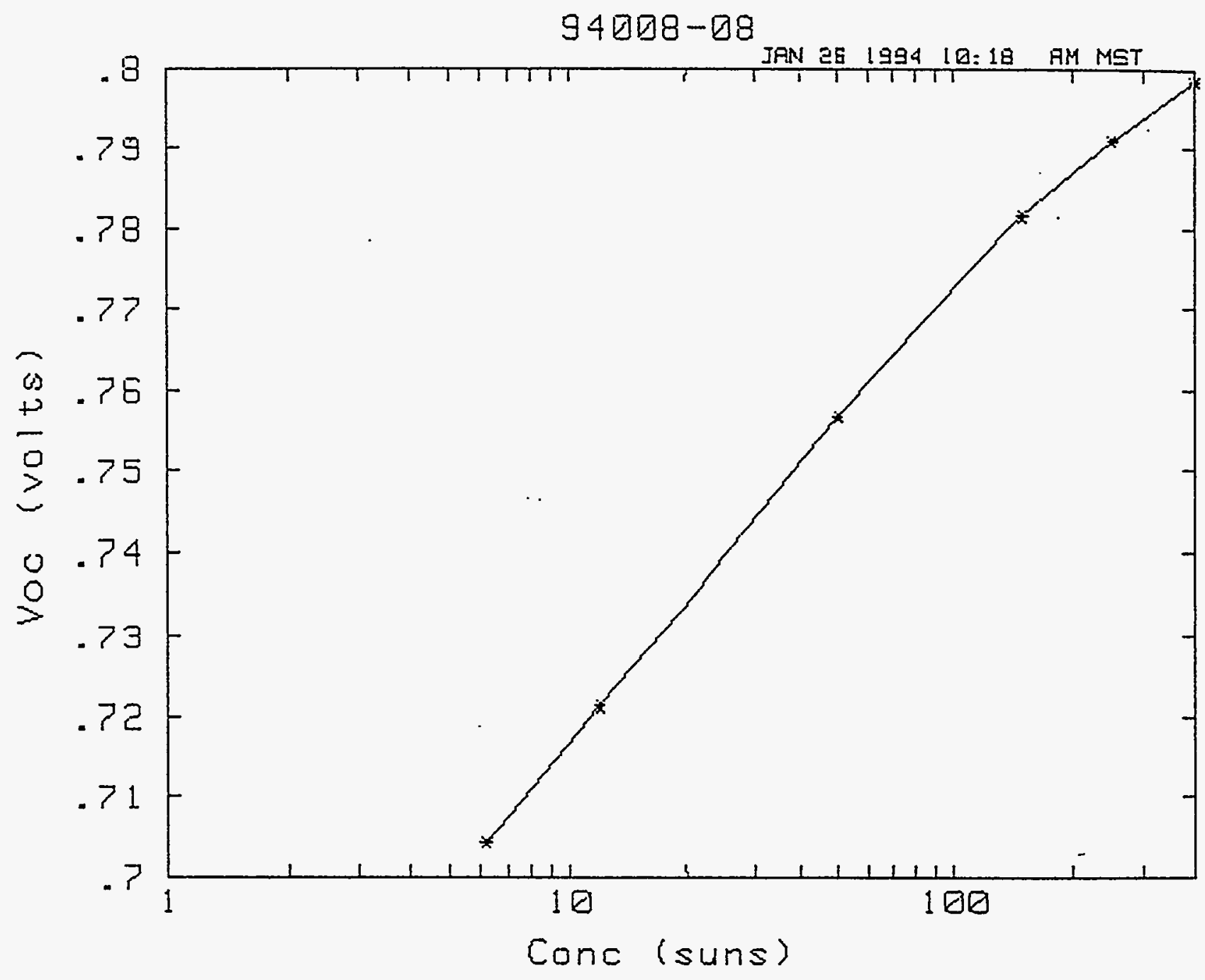

FIGURE 14

Open Circuit Voltage Versus Concentration (Cell \#8) 


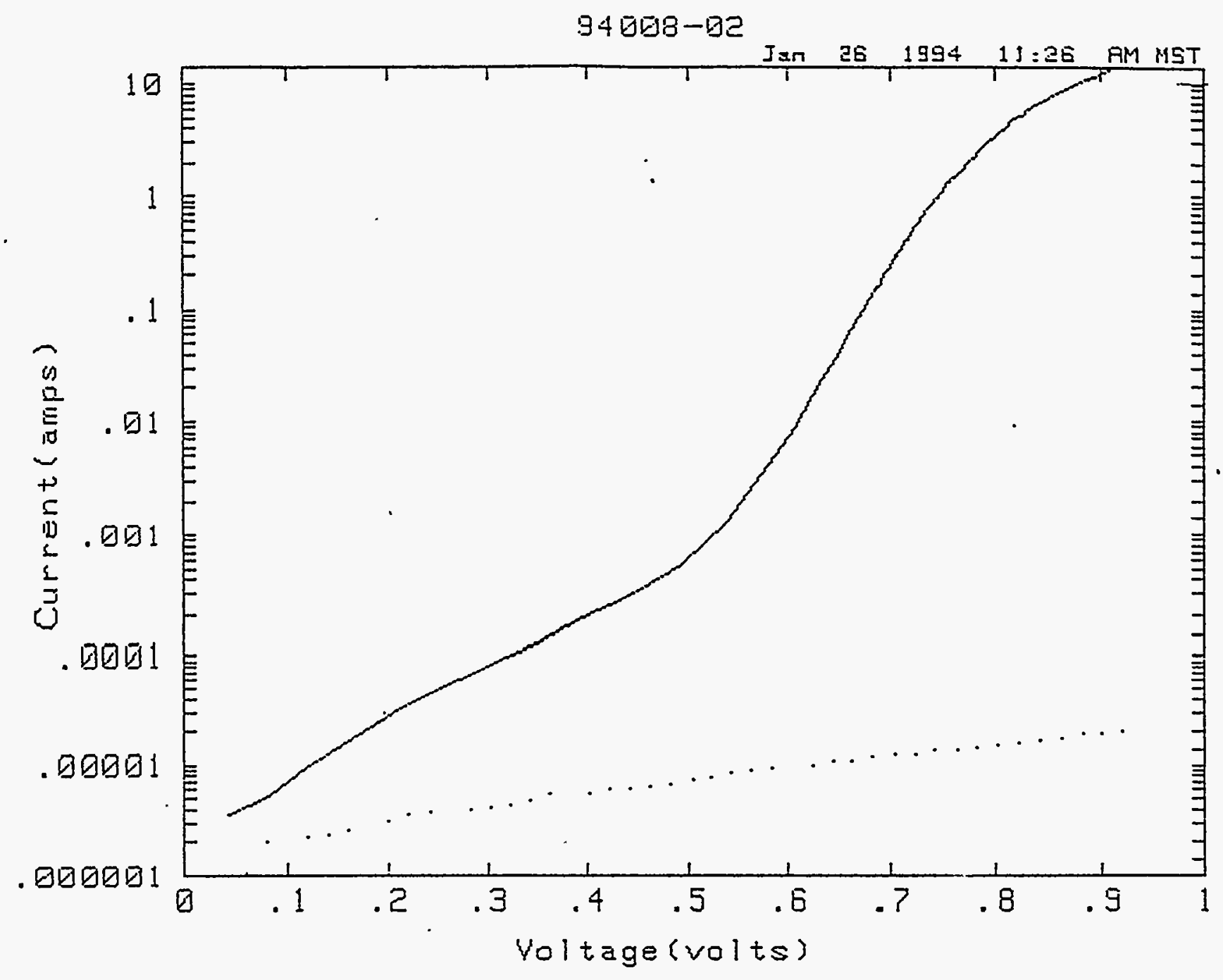

Ce11 I D $=94008-02$

Comment $=212$

Ce11 area $=1.500 \quad c m^{\wedge} 2$

Ce11 Temp $=25.80$ deg $C$

$$
r_{s}=\frac{.91-0.807}{15}=6.7 \mathrm{~m} \Omega
$$

Minimum Current $=1.900 E-06$

amps

Maximum Current $=-1.500 E+01$

amps

Ramp Sweeptime $=100$ ins

Sample Interval $=2.00 \mathrm{~ms}$

$\mathrm{n}=1.07$

FIGURE 15

Dark I-Y Curve (Cell \#2) 


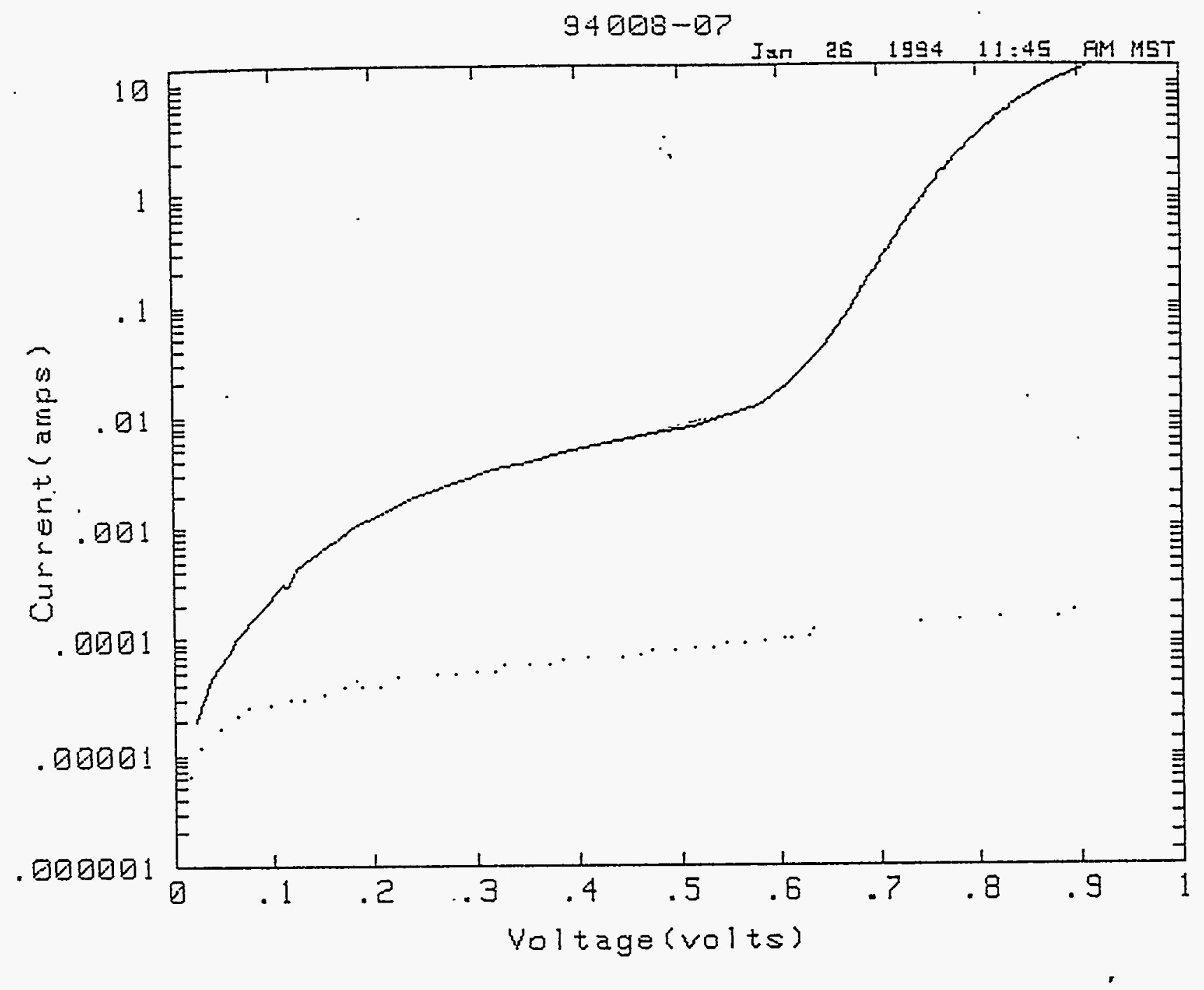

FIGURE 16

Dark I-V Curve (Cell \#7) 
Figure 17 EFFICIENCY vs CONCENTRATION

(Cell \#2)

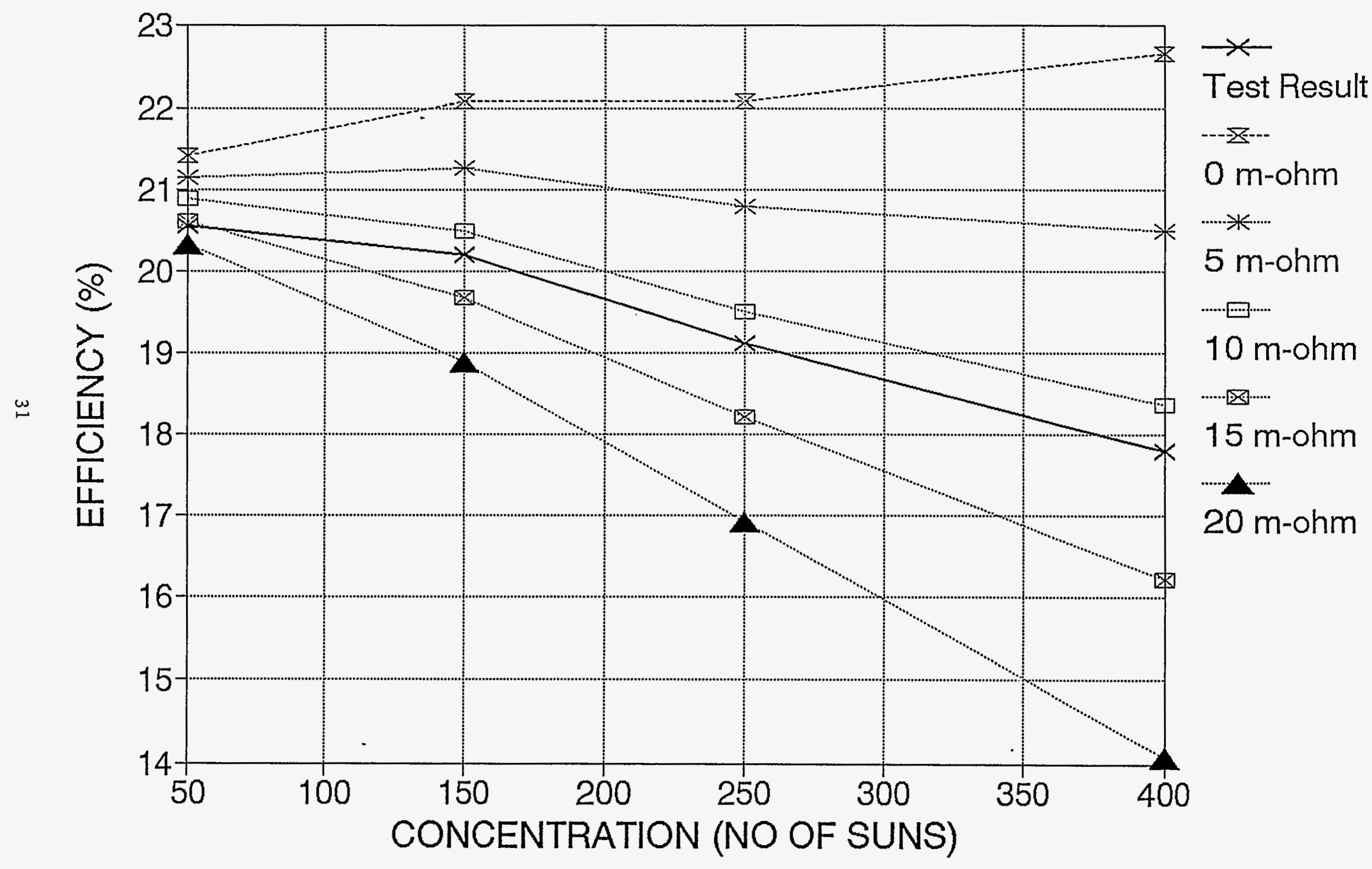


Figure 18 EFFICIENCY vs CONCENTRATION

(Cell \#4)

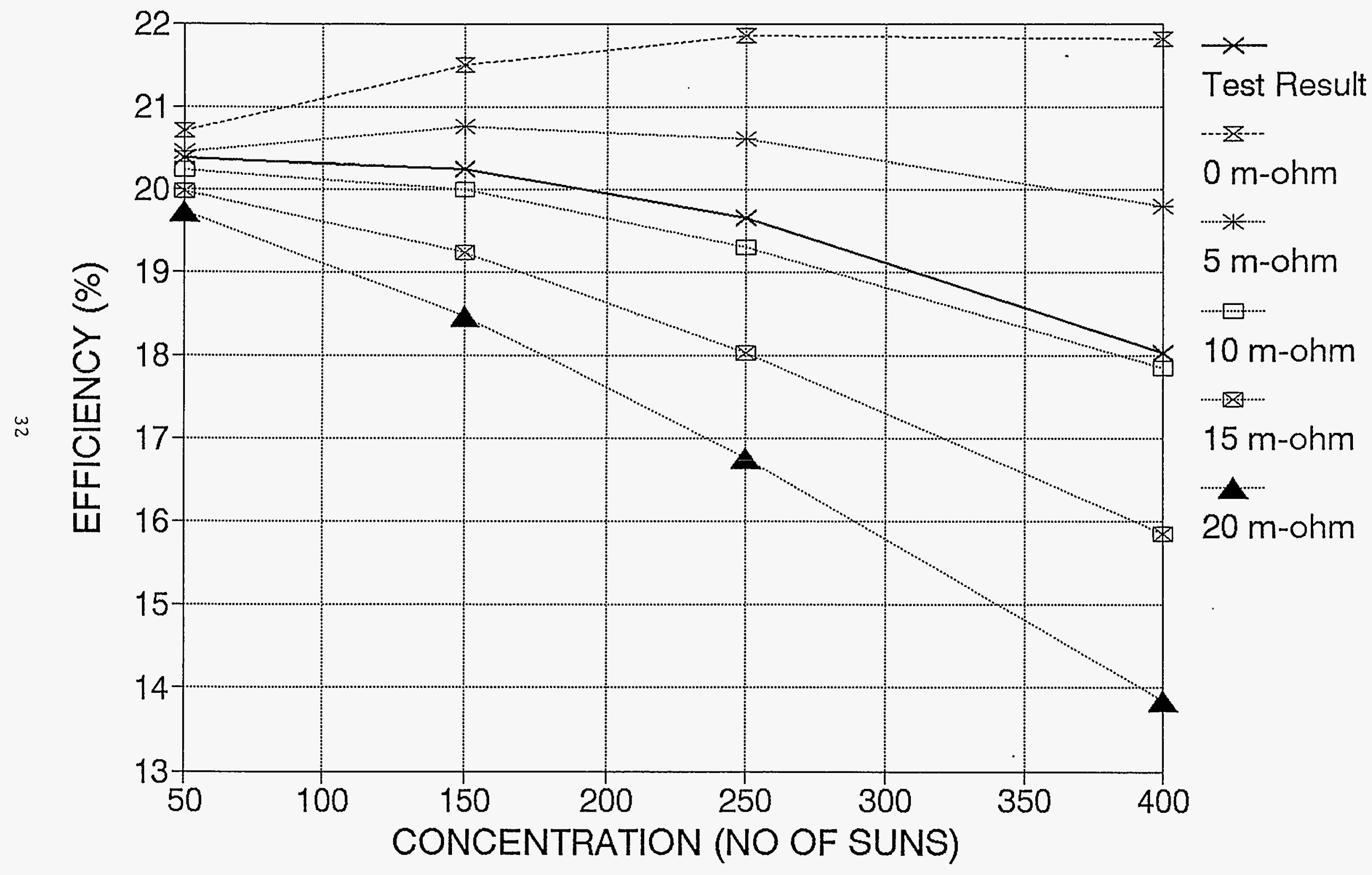




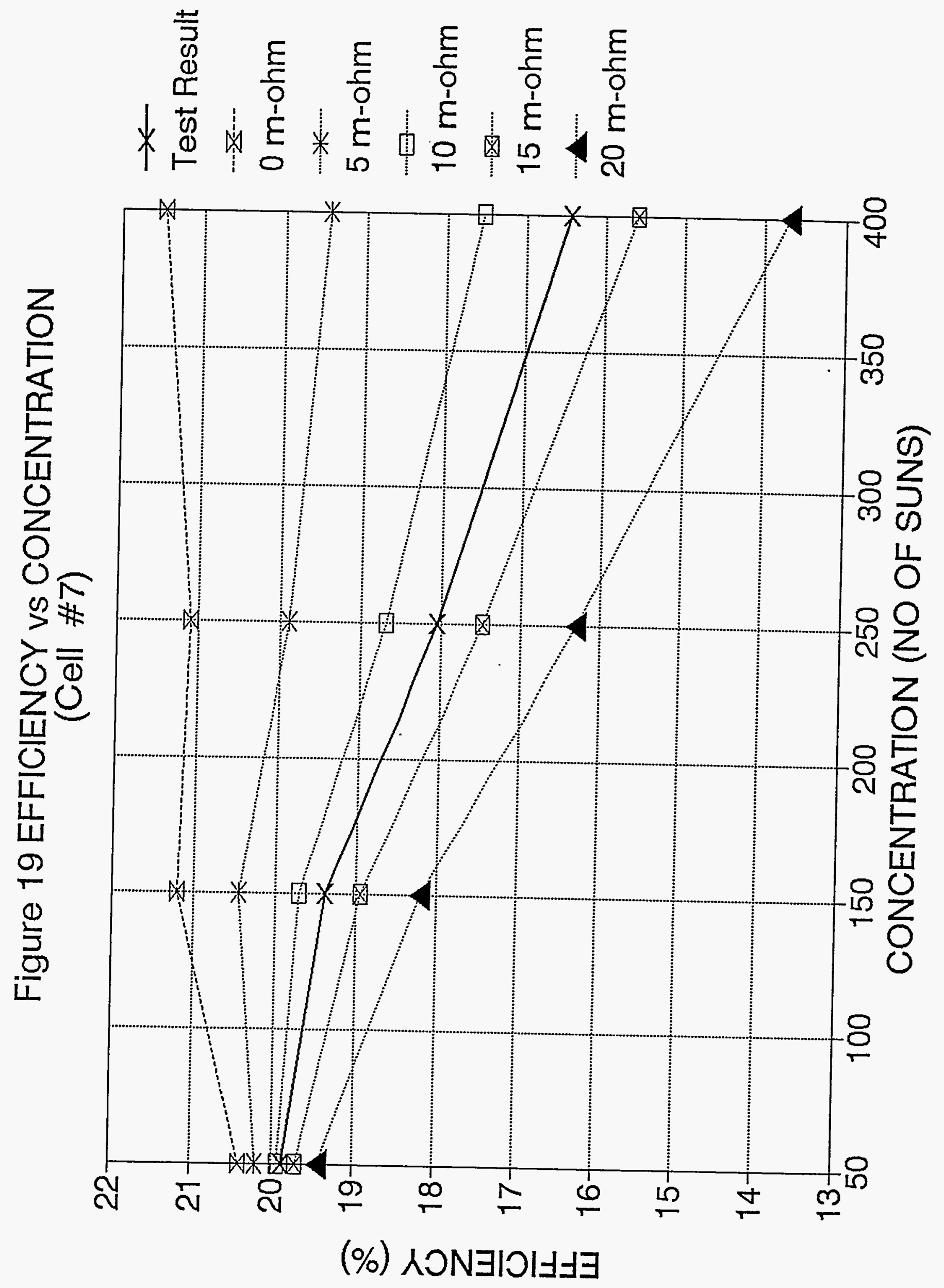




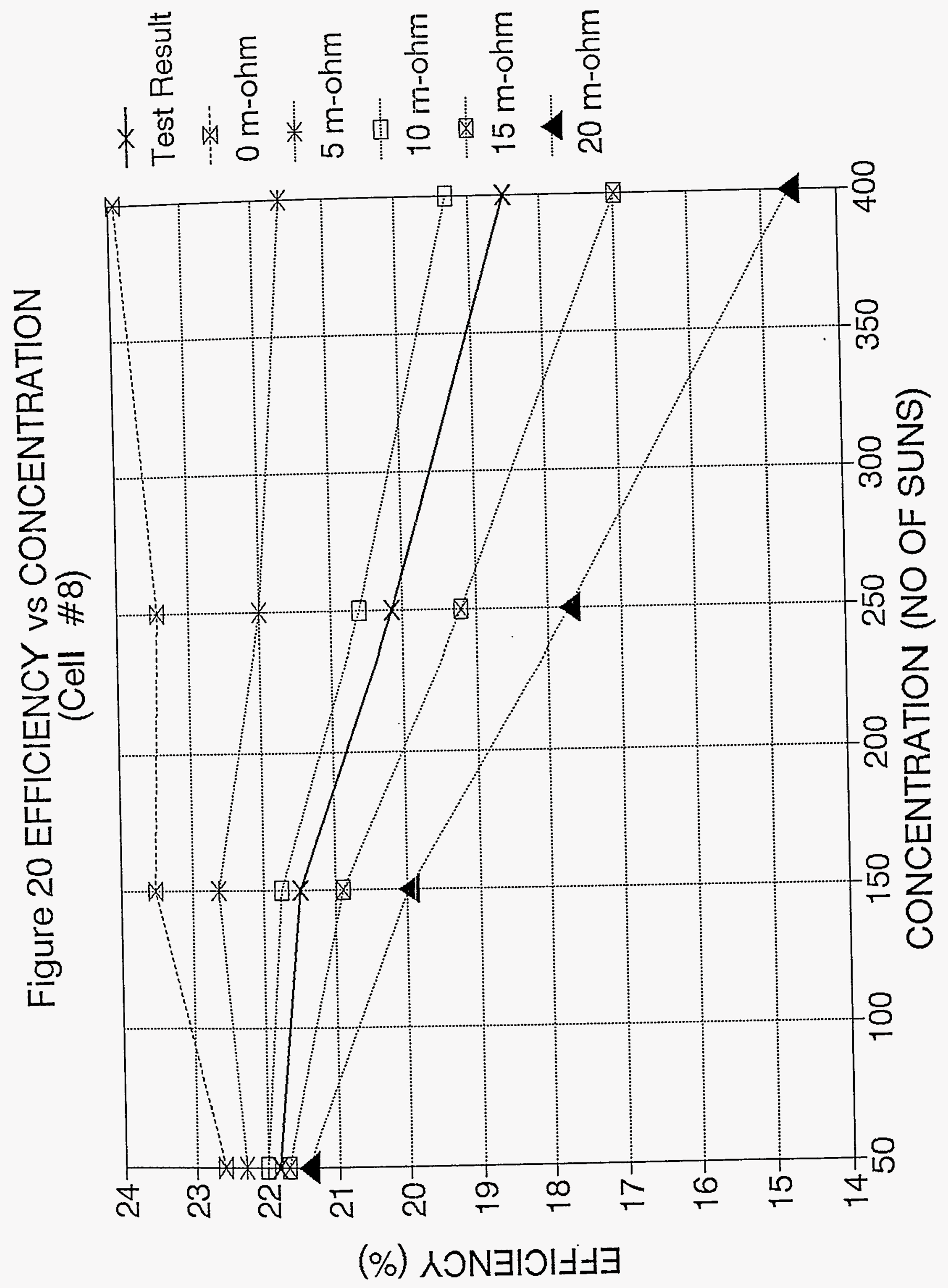


Distribution:

Alpha Solarco

Attn: Anco Blazev

6507 South Hardy Drive

Tempe, AZ 85283

American Optical Corporation

Attn: Clark Grendol

14 Mechanic Street

Southbridge, MA 01550

Amonix, Inc. (2)

Attn: Sewang Yoon

Vahan Garboushian

3425 Fujita Street

Torrance, CA 90505

Applied Solar Energy Corp. (2)

Attn: Frank Ho Henry Yoo

15251 East Don Julian Road

City of Industry, CA 91746

Arizona Public Service Co.

Attn: Thomas Lepley

Mail Stop 9110

Post Office Box 53999

Phoenix, AZ 85072-3999

Arizona Public Service Co.

Star Facility

Attn: Peter Eckert

1500 East University

Tempe, AZ 85281

Arizona State University (3)

College of Engineering and

Applied Science

Attn: Robert Hammond

Charles Backus

Dieter Schroder

Tempe, AZ 85287-5806

Ascension Technology, Inc.

Attn: Miles Russell

Post Office Box 314

Lincoln Center, MA 01773

AstroPower

Attn: Allen Barnett

Solar Park

Newark, DE 19716-2000
Bechtel National, Inc.

Attn: Walter J. Stolte

Post Office Box 3965

Mail Stop 50/15/D17

San Francisco, CA 94119-3965

Black and Veatch

Attn: Kevin Kerschen

Post Office Box 8405

Kansas City, MO 64114

Blue Mountain Energy

Attn: Kay Firor

59943 Comstock Road

Cove, OR 97824

Boeing Aerospace

Attn: Dr. John W. Yerkes

High Technology Center

Post Office Box 3999, MS 7J-71

Seattle, WA 98124-2499

California Energy Commission

Attn: Alexander Jenkins

1516 Ninth Street, MS 43

Sacramento, CA 95814

Mr. Clement Chiang

GE Astrospace, MS NP-2K

100 Nassau Park Boulevard

West Windsor, NJ 08543-800

City of Austin

Electric Department

Attn: John E. Hoffner

Post Office Box 1088

Austin, TX 78767

Cleveland State University

Attn: Jacques Moulot

Dept. of Electrical Engr.

Cleveland, $\mathrm{OH} 44115$

Crystal Systems

Attn: Fred Schmid

27 Congress Street

Salem, MA 01970

Cummings Engineering

Attn: Richard Cummings

323 Andover Street

Wilmington, MA 01887 
Daystar

Attn: Vern Risser

4200 South Research Drive

Las Cruces, NM 88003

DSET

Attn: Gene A. Zerlant

Post Office Box 1850

Black Canyon Stage One

Phoenix, AZ 85020

Endecon

Attn: Chuck Whitaker

3401 Crow Canyon Road

Suite 253

San Ramon, CA 94583

ENTECH

Attn: Mark O'Neill

P. O. Box 612246

DFW Airport, TX 75261

EPRI (3)

Attn: Frank Dostalek John Bigger Frank Goodman

P. O. Box 10412

Palo Alto, CA 94303

G.P.S.

Attn: Howard Somberg

Post Office Box 398

Woodland Hills, CA 91365

Georgia Institute of Technology

(2)

School of Electrical Engr.

Attn: Professor Ajeet Rohatgi

Atlanta, GA 30331

James Associates

Attn: Larry James

7329 Meadow Court

Boulder, CO 80301

Jet Propulsion Lab (2)

Attn: Russ Sugimura

Ron Ross

4800 Oak Grove Drive

Pasadena, CA 91109

Kopin

Attn: Ron Gale

695 Myles Standish Blvd.

Taunton, MA 02780
Massachusetts Institute of

Technology

Attn: Lionel C. Kimerling

77 Massachusetts Avenue

Room 13-5094

Cambridge, MA 02139

Midway Labs

Attn: Paul Collard

77 West Wacker

Chicago, IL 60601

Mobil Solar Energy Corp.

Attn: Juris Kalejs

Four Suburban Park Drive

Billerica, MA 01821

NASA/Lewis Research Center (2)

Attn: Shiela Bailey

MS 302-1

Dennis Flood

21000 Brookpark Road

Cleveland, $\mathrm{OH} 44135$

NREL (5)

Attn: Dick DeBlasio

Laxmi Mrig

Bhushan Sopori

Ted Ciszek John Benner

1617 Cole Boulevard

Golden, CO 80401

NREL Library

1617 Cole Boulevard

Golden, CO 80401

Pacific Gas and Electric (4)

Attn: Steve Hester

Joe Iannucci

Howard Wenger

Tammie Candelaria

3400 Crow Canyon Road

San Ramon, CA 94583

Photonic Power Systems, Inc.

Attn: Jan Werthan

550 California Avenue

Palo Alto, CA 94306 
Public Service Company of New Mexico

Attn: R. Frank Burcham

Alvarado Square, MS 0150

Albuquerque, NM 87158

Purdue University (2)

Attn: Dick Schwartz Jeff Gray

School of Electrical Engr.

West Lafayette, IN 47907

Siemens Solar Industries (2)

Attn: Kim Mitchell Richard R. King

Post Office Box 6032

Camarillo, CA 93011

Mr. Ronald Sinton 4820 La Fiesta Place

San Jose, CA 95129

Solar Engineering Applications

Attn: Neil Kaminar

305 North Mathilda Avenue

Sunnyvale, CA 94086

Solar Kinetics, Inc.

Attn: Shabbar Saifee

P. O. Box 540636

Dallas, TX 75354-0636

Solarex Corporation (2)

Attn: John Wohlgemuth Mohan Narayanan

630 Solarex Court

Frederick, MD 20701

Southern California Edison

Attn: Nick Patapoff

6090 Irwindale Avenue

Irwindale, CA 91702

Southern Electric Int'l.

Georgia Power Research Center

Attn: Edward King

62 Lake Mirror Road, Bldg. 3

Forest Park, GA 30050

SPECO

Attn: Walt Hart

Post Office Box 91

Morrison, CO 80465
Spectrolab (2)

Attn: Dmitri Krut James Albeck

12500 Gladstone Avenue

Sylmar, CA 91342

Spire Corporation

Attn: Michael J. Nowlan

Patriots Park

Bedford, MA 01730

SunPower Corp.

Attn: Richard Swanson

435 Indio Way

Suite 100

Sunnyvale, CA 94086

Suntracker

Attn: Glenn Eiden

302 US 30 East

New Haven, IN 46774

SWTDI

Attn: Steven Durand

Box 30001, Dept. 3SOL

Las Cruces, NM 88003-0001

Texas Instruments

Attn: Jules Levine

Post Office Box 655012

Dallas, TX 75265

Texas Southern University

Attn: V. S. Murty, Physics

3100 Cleburne Avenue

Houston, TX 77004

3M Company

Attn: Paul Jaster, 225-2N-06

3M Center

St. Paul, MN 55144

US Department of Energy

Attn: James Rannels, CE-131

Forrestal Building

1000 Independence Avenue, SW

Washington, DC 20585

Wattsun

Attn: John Doherty

Post Office Box 751

Albuquerque, NM 87103 
Australian National University Attn: Dr. Andres Cuevas Department of Engineering Canberra, ACT 0200 AUSTRALIA

University of New South Wales

Attn: Dr. Martin Green

School of Electrical Engr.

Post Office Box One

Kensington, NSW 2033

AUSTRALIA

Commission of the European

Communities (2)

Joint Research Centre, ESTI

Attn: H. Ossenbrink

TP 450 James Bishop

21020 Ispra, VA

ITALY

Fraunhofer Institute for Solar

Energie Systeme

Attn: Klaus Heidler

Oltmannsstrasse 22

D-7800 Freiburg

GERMANY

Instituto de Energia Solar

Ciudad Universitaria, $\mathrm{s} / \mathrm{n}$

Attn: Antonio Luque

ETSI Telecomunicacion (UPM)

28040 Madrid

SPAIN

0702 D. E. Arvizu 6200

0702 A. VanArsdall 6200

0753 G. J. Jones 6202

0753 C.P. Cameron 6218

0753 P. Valencia 6218

Library 5

0752 M. L. Tatro 6219

0752 D. L. King 6219

0752 P. A. Basore 6219

0752 A. B. Maish 6219

0752 J.M. Gee 6219

0752 D.S. Ruby 6219

0752 W. K. Schubert 6219

0899 Tech Lib. 5 13414

0619 Tech. Pubs. 13416 